\title{
Análisis de caso "Ataque de grupos ilegales contra la población civil de Bojayá” a partir de la polemología y el Derecho Internacional de los Conflictos Armados ${ }^{1}$
}

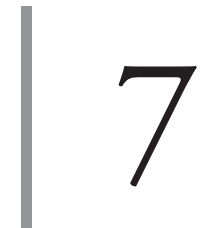

https://doi.org/10.21830/9789585287884.07

\author{
Felipe Andrés Rivera Varón ${ }^{2}$ \\ Escuela Superior de Guerra "General Rafael Reyes Prieto"
}

\section{Resumen}

Este capítulo hace un análisis crítico del conflicto armado colombiano desde el Derecho Internacional de los Conflictos Armados (DICA) y la polemología, a partir del cual se propone un marco conceptual para interpretar el ataque que realizaron integrantes de las Fuerzas Armadas Revolucionarias de Colombia (FARC) e integrantes de las denominadas Autodefensas Campesinas de Córdoba y Urabá (ACCU) contra la población civil de Bojayá el 2 de mayo del 2002. Con este propósito, mediante una metodología de tipo cualitativo en la que se revisaron y analizaron fuentes primarias (normativa sobre los Derechos Humanos y DIH) y secundarias (informes y estudios relacionados con la temática), la investigación aborda tres ejes: (1) la polemología, su relación, contextualización y su incidencia en el conflicto armado colombiano, (2) la relación del DIH y la polemología como fundamento normativo, y (3) la relación entre actores y acciones violatorias de los Derechos Humanos en el ámbito político y social del conflicto armado en Colombia. Se concluye que en la masacre de Bojayá no hubo aplicación del principio de distinción, pues la población civil estaba refugiada en un sitio simbólico y sagrado, lo cual constituye una infracción de la normativa internacional. Además, los resultados de la investigación permiten afirmar que la polemología tiene un papel muy importante en la comprensión y resolución de los conflictos armados, ya que busca hacer efectivas las garantías de no repetición, considerada una de las formas de reparación a las víctimas y uno de los principios generales de responsabilidad internacional de los Estados.

1 Este capítulo expone los resultados del proyecto de investigación "Esclarecimiento de la verdad histórica sobre la violencia estructural en Colombia, provocada al medio ambiente y a las víctimas del conflicto: Aporte de las Fuerzas Militares en la reconstrucción del tejido social", del grupo de investigación Memoria Histórica, Construcción de Paz, Derechos Humanos, DICA y Justicia, de la Escuela Superior de Guerra "General Rafael Reyes Prieto", registrado con el código COL0141423 y categorizado en C por Minciencias. Los puntos de vista pertenecen al autor y no reflejan necesariamente los de las instituciones participantes.

2 Magíster en Derechos Humanos y DICA de la Escuela Superior de Guerra "General Rafael Reyes Prieto”, Bogotá, D. C., Colombia. Especialista en Explosivos de la Escuela de Ingenieros Militares. Ingeniero industrial. ORCID: https://orcid.org/0000-0003-0432-577X. Contacto: felipe.rivera@esdegue.edu.co. 
Palabras clave: Bojayá, Chocó; Derecho Internacional de los Conflictos Armados; Derecho Internacional Humanitario; polemología.

\section{Introducción}

La revisión de la literatura relacionada con este campo de estudio permite destacar los siguientes autores: Aznar y Montesinos (2011), Bouthoul (1946), Clausewitz (2002), Galtung (2004), Martínez (2003) y Molina (2000). Asimismo, de acuerdo con el estudio titulado La guerra como objeto de estudio de las ciencias sociales. Consideraciones desde la sociología, realizado por el Departamento de Economía de la Universidad Nacional del Sur de Argentina, se establece que existen estudios y publicaciones sociológicos sobre la guerra. Sin embargo, en la mayoría de los casos se han limitado a analizar una acción bélica que consiste en la utilización de armamentos, e incluso de armas de destrucción masiva, con enfoques unilaterales y parciales, dejando de lado el aspecto sociológico que también concierne al estudio. De este modo, surge la necesidad de investigar los conflictos armados y poder llegar a reducir de una manera paulatina las consecuencias y buscar soluciones que denoten la importancia de la paz (Villafañe, 1971, p. 148).

Teniendo en cuenta lo anterior, una perspectiva que permitiría entender la guerra desde un enfoque diferente es la polemología, la cual es considerada como la "ciencia de las guerras". En este contexto, surgen dos pensadores militares de los últimos tiempos: Carl von Clausewitz, quien concibe que "la guerra es una continuación de la política por otros medios", es decir, la violencia organizada, y el general francés Antoine Henri Jomini, el cual considera que se debe codificar el comportamiento para instruir mejor a los oficiales sobre cómo organizar, planear y conducir la "guerra moderna".

En este sentido, es importante analizar la definición de guerra, entendida como la confrontación armada entre dos o más Estados que implica el uso de la fuerza, de acciones, actores y circunstancias que determinan el cese del estado de paz (Verri, Duque \& Cabrera, 2008). Asimismo, es pertinente tener en cuenta las causas que generan los conflictos armados o guerras alrededor del mundo. Existen aspectos tan importantes de la guerra que hacen necesario un estudio científico y objetivo del "fenómeno de la guerra", de tal manera que se debe distinguir la ciencia militar de la guerra. En este sentido, Gastón Bouthoul (1946), en Polemología o guerra, considera que el fenómeno social es la causa de la guerra desde diversos ámbitos, como el económico, el político, el social, entre otros.

De este modo, Bouthoul (1946) interpreta la guerra como una actividad en la que únicamente los pueblos que sean económicamente fuertes pueden permitirse el 
"lujo" de irrumpir y desatarla. Por su parte, agrega, aquellos que se atreven a hacer las guerras sin tener ese potencial económico carecen del sustento necesario para mantenerla, por lo cual recurren a terceros para que les brinden apoyo económico, pero con la condición de que exista un compromiso vinculante.

Específicamente, en Colombia, la utilización e implementación del Derecho Internacional de los Conflictos Armados (DICA) ha constituido un desafío que ya no solo es aplicable al ámbito rural, en donde se ha desarrollado la mayor parte del conflicto, sino que la violencia poco a poco se ha ido desplazando también hacia las zonas pobladas y cascos urbanos. Como consecuencia, se ha evidenciado un cambio significativo en la forma de pensar el conflicto y otras situaciones de violencia, así como lo ha hecho la forma en que combaten entre sí los actores armados (Restrepo \& Aponte, 2009).

El conflicto armado en Colombia se ha desarrollado durante décadas de manera asimétrica ${ }^{3}$. Este inició en la década de los sesenta y desde entonces ha tenido como principales actores al Estado y quienes se enfrentan a él desde la ilegalidad, como las guerrillas, los paramilitares, las bandas criminales (BACRIM) ${ }^{4}$ y los carteles de la droga. El narcotráfico es un aspecto nodal que profundiza el conflicto armado colombiano debido a que sus altas rentas incentivan la ilegalidad, la corrupción y el clientelismo, lo cual trae como consecuencia una lógica de "economías ilegales" que aumentan la violencia cotidiana en territorios vulnerables del país, principalmente por las rutas, los laboratorios y los demás aspectos relacionados con la producción de la actividad ilegal (Restrepo \& Aponte, 2009).

En este escenario, el DICA permite abordar el tema del conflicto armado en Colombia, específicamente para analizar el ataqué de Bojayá, pues esta normativa limita los medios y métodos del conflicto, principalmente frente al adversario, con el fin de minimizar sus efectos y, con ello, los sufrimientos innecesarios. Así, mientras la polemología permite entender la dinámica sociológica del desarrollo de una guerra en los diversos ámbitos en los cuales llega a tener impacto, o en este caso un conflicto, el DICA permite establecer parámetros y regular las actuaciones que se desarrollen en un campo de acción más amplio para entender la guerra.

3 Es decir, “[...] cuando los actores enfrentados tienen diferentes capacidades para efectuar, desarrollar y activar las acciones propias del enfrentamiento armado. Colin Gray (2000) explica que este tipo de confrontación se basa en lo inusual y lo inesperado, en donde se presentan procedimientos con métodos no convencionales (IEGAP, 2011, p. 2)” (Garay \& Ramírez, 2017, p. 423).

4 A partir de la Directiva Ministerial n. ${ }^{\circ} 15$ del 2016 se denominan Grupos Armados Organizados Residuales (GAOR) y Grupos Delictivos Organizados (GDO) (Ministerio de Defensa Nacional, 2016). 
En este sentido, hay que entender que los conflictos armados son tan antiguos como la misma humanidad, de forma que los impactos y efectos derivados de estas confrontaciones armadas obligaron a los Estados a formular normas internacionales con la finalidad de disminuirlos. Con este propósito fueron creados los Convenios de Ginebra y de La Haya, destinados a proteger a las víctimas de la guerra y regular la conducción de hostilidades (Comité Internacional de la Cruz Roja [CICR], 2001). Esta rama del derecho se conoce por lo general también como "derecho de la guerra" (Gasser, 1998; Ruiz, 2011).

A continuación se presentan los posibles acercamientos conceptuales sobre el Derecho Internacional Humanitario [DIH] y el DICA desde la academia:

- DIH. De acuerdo con Swirnarski (1990), el DIH es el conjunto de normas internacionales, de origen convencional o consuetudinario, específicamente destinado a ser aplicado en los conflictos armados internacionales o no internacionales y que limita, por razones humanitarias, el derecho de las partes en conflicto a escoger libremente los métodos y los medios utilizados en la guerra (Derecho de La Haya), o que protege a las personas y a los bienes afectados (Derecho de Ginebra).

- DICA. De acuerdo con el diccionario de Verri et al. (2008), es la parte del derecho internacional público que determina las normas de comportamiento de los actores que forman parte de los conflictos armados de tipo internacional. De este modo, su propósito se enmarca en la limitación para que las fuerzas comprometidas en el conflicto causen el menor daño posible a las personas que de una u otra manera se ven inmersas en las confrontaciones bélicas y que por consecuencia de ellas se convierten en víctimas.

En este escenario, el DICA es una parte fundamental del derecho internacional público (DIP) que establece las normas de comportamiento de los actores en un conflicto interno. Asimismo, el DIH tiene como fundamento proteger la vida, la salud y la dignidad de las personas, así como regular en términos humanitarios el desarrollo y los efectos de la guerra o conflicto (Organización de las Naciones Unidad [ONU], 2011; Valencia, 1989). Por esta razón, es importante estudiar el concepto de DICA junto con la polemología para tener una mejor comprensión del conflicto armado colombiano.

Conforme a lo anterior, este trabajo plantea la siguiente pregunta de investigación: ¿De qué manera se manifiesta la influencia de la polemología en el ataque de grupos ilegales contra la población civil de Bojayá (Chocó) el día 2 de mayo del 
2002 a partir del Derecho Internacional de los Conflictos Armados? Para responderla, se empleó una metodología de tipo cualitativo a partir del análisis y revisión de fuentes primarias (normativa sobre los Derechos Humanos y DIH) y secundarias (informes e investigaciones relacionadas con la temática). Específicamente, la metodología del análisis documental se basó en el trabajo de Hernández et al. (2014) y Guadarrama (2016) (tabla 1).

Tabla 1. Comparación de los conceptos sobre métodos para realizar una investigación científica

Hernández et al. (2014): Metodología de la investigación

Enfoque cualitativo: utiliza la recolección y análisis de los datos para afinar las preguntas de investigación.

Estudios descriptivos: buscan especificar propiedades y características importantes de cualquier fenómeno que se analice. Describe tendencias de un grupo o población. Es decir, únicamente pretenden medir o recoger información de manera independiente o conjunta sobre los conceptos o las variables.

Análisis documental y de información: es una forma de investigación técnica, un conjunto de operaciones intelectuales que buscan describir y representar los documentos de forma unificada y sistemática para facilitar la recuperación.
Guadarrama (2016): Dirección y asesoría de la investigación científica
Investigación cientifica: es un acto de plena conciencia, responsabilidad intelectual, cultural y social que exige prepararse adecuadamente para emprenderla con todas sus consecuencias. Este libro sugiere algunas propuestas que sirven como fundamento conceptual a los investigadores a partir de la precisión de los fundamentos filosóficos y epistemológicos que deben orientar las investigaciones científicas.

También ofrece pautas, herramientas básicas de trabajo científico en el orden metodológico a los investigadores que dirigen o realizan proyectos de investigación o de tesis y coordinan grupos de investigación científica.

Fuente: Elaborado por el autor.

Este capítulo se divide en tres partes que desarrollan el tema de manera articulada. En primer lugar, se explica la polemología, su relación y contextualización en el conflicto armado colombiano. En segundo lugar, se aborda la relación del DIH y la Polemología como fundamento normativo a partir del ataque de grupos ilegales contra la población civil de Bojayá. En tercer lugar, se analiza la relación entre actores y acciones violatorias de los Derechos Humanos en el ámbito político y social del conflicto armado en Colombia en Bojayá. Finalmente, se presenta una serie de conclusiones pertinentes para futuras investigaciones sobre la temática estudiada. 


\section{La polemología, su relación y contextualización en el conflicto armado colombiano}

\section{Desarrollo conceptual e histórico de la polemología}

La polemología empezó a tener auge en la mitad del siglo XX con la publicación del Tratado de polemología de Gastón Bouthoul (1946). Considerado como el padre ${ }^{5}$ y fundador de esta ciencia, Bouthoul (1946) señala que este concepto surge en la medida en que sea posible estudiar y analizar las guerras o conflictos, así como resolver los factores que las promuevan para poderlas dirimir.

En este sentido, la polemología se entiende como "el estudio científico de la guerra y de los conflictos; [...] estudia de estos: la naturaleza y la morfología, la localización en el tiempo y en el espacio, la periodicidad, la intensidad, las causas, los encadenamientos y las funciones, la tipología" (Queirel, 2018, p. 31). Aborda, por tanto, el fenómeno del conflicto armado $^{6}$ alrededor del mundo, centrado fundamentalmente en las causas económicas, geográficas y psicológicas que los generan. Es decir, ese análisis de la guerra no trata solamente las causas eventuales o superficiales que inician el conflicto (Bouthoul, 1946), sino que se considera que la polemología es la ciencia y sociología que estudia las causas profundas y determinantes que provocan las guerras con el fin de evitarlas en el futuro (Fisas \& Mayor, 2006).

En cuanto a la concepción de la guerra, es importante mencionar el trabajo del doctor en ciencia política Federico Aznar Fernández en el campo de la irenología ${ }^{7}$ especialmente los parámetros que plantea Aznar y Montesinos (2011) para comprender este fenómeno desde la filosofía de la guerra:

5 Si bien el autor es considerado como el padre de esta ciencia, en la misma época en que surgió el concepto se encuentra el trabajo de Julien Freund, quien, a diferencia de Bouthoul, entiende la polemología "como el estudio del conflicto en general, fuese de naturaleza económica, religiosa, jurídica, política o de otro tipo” (Molina, 2000, p. 203). Por esta razón, este trabajo se centra en los aportes de Bouthoul, en la medida en que considera que la guerra puede ser originada por diferentes factores y, por lo tanto, se debe estudiar de forma particular. En contraste, Freund sostiene que se debe estudiarla y analizarla independientemente de las causas.

6 En este trabajo se entiende como conflicto armado la lucha armada entre grupos organizados de un territorio y otro o que se puede dar en una zona geográfica dentro de un Estado. De acuerdo con el Comité Internacional de la Cruz Roja (CICR), en el artículo 2. ${ }^{\circ}$ Común de los Convenios de Ginebra se entiende que la guerra o el conflicto armado se da entre Estados, mientras que otras organizaciones, como ACNUR, los definen como un "enfrentamiento violento entre dos grupos humanos de tamaño masivo y que, generalmente, tendrá como resultado muertes y destrucción material” (Verri et al., 2008).

7 Esta ciencia estudia la paz y los conflictos con ideas, medios y acciones para que se puedan canalizar hacia una solución por medios pacíficos, sin recurrir a la violencia, de tal manera que la sociedad genere una condición óptima. 
1. La polemología como ciencia: polemos, en griego, significa 'lucha', 'guerra'. Si antes la historia se entendía como una sucesión se monarcas, guerras y batallas, hoy esta palabra está tergiversada. Su uso ha quedado proscrito y su nombre resulta incómodo por las connotaciones e implicaciones que la acompańan.

2. Hacia una definición de la guerra: la guerra no es un concepto estático; sus límites, además, son imprecisos, en la medida en que no los marca necesariamente la violencia.

3. Guerra y política: la naturaleza de la guerra es instrumental, ya que, como apuntaba Clausewitz (2002), sirve a un objetivo político: "El objetivo de la acción guerrera es un equivalente del fin político". La guerra no tiene sentido en sí misma; tiene una finalidad y un sentido político, es la política la que marca el "para qué" de la guerra. En este sentido, la naturaleza de los fines está afectada por la naturaleza de los medios.

4. Características de la guerra: para acabar con las guerras causales es necesario hacerlo de modo indirecto y atacar las causas que las provocan.

Por su parte, en La naturaleza de la guerra, Clausewitz (2002) identificó su esencia en el duelo: "La guerra no es más que un duelo en una escala ampliada", una idea que complementa los aportes que los estudios de la guerra pueden brindar a la renovación del paradigma de desarrollo (ahora entendido definitivamente como sostenible) y la reconfiguración de la relación entre Derechos Humanos, cooperación y desarrollo sostenible. En palabras de Surasky (2017), "parte de recuperar el lazo entre cooperación y conflicto, busca una aproximación para hallar nuevas comprensiones y herramientas para avanzar en la concreción del derecho humano al desarrollo sostenible" (p. 1).

Aunque hoy día todavía se controvierte en el mundo la idea inicial de los pioneros de la polemología, según la cual el fenómeno de la guerra puede constituir un objeto científico propio, la polemología científica se concibió como la base para elaborar una teoría general de las guerras, que trata de elaborar un cuadro lógico abstracto, suficientemente amplio para permitir estudiar las propiedades particulares. En otras palabras, la actuación científica que propone consiste, en un extremo, en demostrar sus hipótesis teóricas mediante la elaboración de modelos lógicos y, en el otro, en confrontar los modelos que ha construido con las bases empíricas disponibles (Schmidt, 1981).

Este aspecto demuestra que su esencia y carácter son verdaderamente científicos, pues para investigar y trabajar sobre un hecho o un tema no basta simplemente con estudiarlo de forma aislada, sino que es necesario estudiarlo comparativamente, 
cotejándolo o confrontándolo con otros análogos, de modo que se perciba con todas sus características dentro de un sistema y no como un fenómeno aislado (Martínez, 2003).

En este contexto, es necesario señalar que muchos estudios sobre conflictos y paz pretenden ser una disciplina sobre la resolución de conflictos, e incluso tienen una Asociación Internacional de Investigación de la Paz, patrocinada por la Organización de las Naciones Unidas para la Educación, la Ciencia y la Cultura (Fisas \& Mayor, 2006). Sin embargo, aunque el nombre de conflicto y estudios de paz expresa cierto dilema que ha estado presente en la disciplina desde el principio, una disciplina centrada en el conflicto tiene mucho sentido, ya que este es considerado como un fenómeno prácticamente universal en todos los sistemas sociales ${ }^{8} \mathrm{y}$, de hecho, en algunos biológicos. En contraste, la investigación sobre la paz siempre ha sido normativa, en el sentido de que ha sido practicada por personas que son profundamente conscientes de las patologías del conflicto y que desean hacerlo lo más barato y productivo posible (Kenneth, 1978).

En este sentido, para la polemología la gestión de los conflictos es comparable, por ejemplo, a lo que la economía del bienestar es para la economía positiva. Es un intento de derivar lo que casi se podría llamar una "mínima normatividad". Por lo tanto, los estudios de paz y conflicto incluirían la polemología como una disciplina positiva, mientras que el manejo de conflictos sería una disciplina normativa, al igual que la economía también incluye aspectos tanto positivos como normativos.

Por ejemplo, para entender bien el concepto de la historia militar ${ }^{9}$ se deberían tener en cuenta otros géneros históricos, como el de historia de la ciencia, por cuanto esta disciplina no solo estudia los grandes descubrimientos científicos y las personalidades de sus inventores, sino también los medios utilizados (desde el telescopio de Galileo a las lentes apocromáticas de Abbe, y desde el microscopio a los instrumentos de tomografía), las máquinas (como la de vapor, de James Watt), las fuentes de energía (desde la eólica y de vapor a la eléctrica y la atómica) y su aplicación a la producción (desde el horno Siemens a la tecnología del láser, y desde el motor de explosión a la informática). Y a ningún historiador le extrañan esos objetos de estudio para abarcar con profundidad y sistematicidad los conoci-

8 Los patrones de conflicto tienen ciertas similitudes en las diversas situaciones en las que se presentan. Desde una perspectiva axiológica, se pueden encontrar en la familia, la organización, las relaciones industriales, la iglesia, la ciencia, entre las naciones e incluso dentro de la propia personalidad — de hecho, los franceses y los holandeses le han dado a esta disciplina el nombre de polemología-.

9 Además de la definición que se ha hecho de la polemología, esta también profundiza la esencia, los contenidos y las fuentes de la historia militar con el propósito de formular una aproximación a lo que debe ser su metodología. 
mientos propios de una historia de la ciencia, a la que nadie negó jamás su carácter científico (Martínez, 2003). Por lo tanto, se puede decir que estas recomendaciones sobre diferentes géneros históricos permiten analizar y comprender las causas de las guerras desde diferentes perspectivas, con lo cual se podría evitar guerras futuras realizando estudios científicos a fondo.

Ahora bien, en concordancia con su estatus de ciencia, la polemología científica y las premisas de una "ciencia de la guerra" se desarrollan en institutos especializados, como el Centro Belfer para la Ciencia y los Asuntos Internacionales, de la Harvard Kennedy School, que es el encargado de la investigación, la enseñanza y la capacitación en materia de seguridad internacional y diplomacia, cuestiones ambientales y de recursos, y política de ciencia y tecnología. El Centro Belfer tiene como misión proporcionar liderazgo para avanzar en el conocimiento relevante de las políticas sobre los desafíos más importantes de la seguridad internacional y otros temas críticos en los que se interceptan la ciencia, la tecnología, la política ambiental y los asuntos internacionales (Harvard Kennedy School, 2019).

También se debe mencionar la Escola de Cultura de Pau (ECP), que se creó en Barcelona en 1999 con el propósito de trabajar por la cultura de paz, los Derechos Humanos, el análisis de conflictos y de los procesos de paz, la educación para la paz, el desarme y la prevención de los conflictos armados. Específicamente, la ECP tiene los siguientes objetivos: promover la comprensión y la práctica de la cultura de paz, investigar e intervenir en temáticas relacionadas con los conflictos, los procesos de paz, la dimensión de género en la construcción de paz y la educación para la paz, formar personas para que sean capaces de difundir el mensaje y la práctica de la cultura de paz (ECP, 2017).

En el contexto colombiano se debe mencionar el Centro de Investigación y Educación Popular (CINEP) / Programa por la Paz. Es una institución fundada por la Compañía de Jesús hace más de cuatro décadas que construye conocimiento y sistemas de información por medio del desarrollo de cinco líneas de investigación histórica y estructural sobre la realidad colombiana: (1) el conflicto, la violencia y la construcción del Estado; (2) la movilización social y la realización de los derechos fundamentales; (3) el reconocimiento y visibilidad de la memoria de las víctimas a quienes les han violado sus derechos civiles y políticos; (4) el análisis y las alternativas sobre el desarrollo desigual, y (5) el estudio y seguimiento a las iniciativas, la movilización y los diálogos de paz. De esta manera, CINEP/PPP contribuye no solo a crear propuestas hacia una sociedad justa, sostenible y en paz en Colombia, sino además a conciliar el conflicto social del país con su trabajo y presencia en distintas redes, escenarios y regiones. Asimismo, contribuye a la construcción de 
"puentes" y relaciones entre distintos sectores de la sociedad, el Estado, los movimientos sociales, la academia, las iglesias, gremios y actores privados, y participa en procesos de debate y concertación social, en escenarios de incidencia en la opinión pública y de definición de políticas públicas (CINEP, s. f.).

\section{Violencia, conflicto y guerra en la polemología}

La concepción occidental ha dado una interpretación negativa al conflicto, de tal manera que se evita y no se desea, pues cuando se desarrolla, se pueden presentar acciones violentas que lo convierten en un "conflicto violento". Cuando se intensifica en diversas variables, como armamento, tiempo, extensión, entre otras, se consolida como una "guerra" que se desarrolla principalmente en dos fases: la ofensiva y la defensiva. Sin embargo, la violencia ha estado presente en las sociedades humanas a través de elementos como la jerarquía, la desigualdad social, la intolerancia, la discriminación, entre otros (Villafañe, 1971).

En este sentido, la guerra es un fenómeno social que, como todos los fenómenos sociales, tienen sus causas y motivos a los que obedecen y cuyo conocimiento nos proporciona la polemología. Por un parte, se considera que la guerra es la manifestación de desequilibrios sociales, principalmente demográficos y geográficos —una reacción característica de la psicología social que Villafañe (1971) considera una "impulsión belicosa colectiva"-, y puede surgir por diferentes causas económicas, políticas, religiosas, culturales, territoriales, administrativas, entre muchas otras. En este escenario, la agresividad en las clases económicas surge porque aumenta el fracaso económico y político, el cual lleva a que sus dirigentes - la administración o quien haga las veces del partido en el poder - y los partidos que están en contraposición a sus intereses busquen en la violencia una posible solución. Desde la perspectiva de la psicología social, estos fenómenos constituyen reacciones comportamentales individuales frente a situaciones que, según la posición de cada pueblo o dirigente de partido, conducen finalmente a una guerra o conflicto armado (Bouthoul, 1946).

Por otra parte, el principal detonante del conflicto es la necesidad de acumulación de capital para personal militar, armamentos y víveres. Como se había mencionado, los pueblos que sean económicamente fuertes pueden permitirse el "lujo" de irrumpir y desatar una guerra, mientras que aquellos que se atreven a hacer la guerra sin tener ese potencial económico deben recibir en ocasiones "ayudas", que los comprometen con quienes las suministran (Bouthoul, 1946).

En todos los casos, las acciones armadas son igual de dolorosas y sus consecuencias son en su mayoría efectos ligados a homicidios, destrucción, desolación y 
deterioro de la población y los territorios afectados (Bouthoul, 1946). De acuerdo con Villafañe (1971), las características y consecuencias de la guerra generan reacciones de frustración y depresión en las multitudes, a pesar de que sean pasivas, sumisas y conformistas. También es verdad que estas son fácilmente sugestionables (y bien saben aprovecharse de esto los agitadores políticos), por lo cual la guerra rebasa las conductas que los actores que la componen harían individualmente, como las destrucciones y las masacres.

Para Gasser (1998) y Borda (2007), el conflicto armado trae consecuencias catastróficas y produce sentimientos de amargura, tristeza, desolación y vulnerabilidad debido a sus efectos devastadores, como muertes y mutilaciones de todo tipo, abusos, asesinatos y violencia sin fin, que muchas veces es difícil de controlar, revertir o superar. En palabras del sociólogo y matemático noruego Galtung (2004):

Los conflictos aparecen como una constante en la historia de la humanidad y en algunas etapas de la historia generaron verdaderos cambios en provecho del hombre, pero en otras, trascendiéndose a sí mismos y convirtiéndose en violencia que conllevaría hacia la deshumanización absoluta. De ahí su importancia, sentido para la vida y el destino de las personas. (Galtung, 2004; citado por Calderón, 2009, p. 61)

Como se ha descrito, dado que cualquier fenómeno de violencia tiene diferentes niveles de causas: de tipo estructural, coyuntural, ocasional y motivacional, para garantizar la paz no solo es necesario adoptar medidas preventivas, sino también analizar las causas o aspectos de los fenómenos bélicos que conducen a las funciones de la guerra. Para ello, es preciso tener en cuenta que, en ese nivel, cuanto más profunda y duradera sea la motivación analizada, menor será su manifestación y, por tanto, los desequilibrios correspondientes serán más difíciles de detectar (Bouthoul, 1946).

La diferencia entre fuerza y violencia se encuentra en una evanescente cuestión de legitimidad que hace que la guerra se desinstitucionalice y retorne a los viejos modos prewestfalianos, cuando se hacía entre grupos armados; ocasionando la aparición de monopolios de violencia caracterizados por una parte por el Estado como actor central y por la otra grupos y agentes transnacionales que la desarrollan, distinción entre la guerra y el crimen para hacerse depender de la fuerza y de la consolidación de una situación de victoria (Aznar \& Montesinos, 2011); así y todo la guerra se hace hacia el interior y la función policial se desarrolla hacia el exterior, que hace que la guerra sea un concepto que no recoja todos los casos categorizables de procesos violentos que implican a grupos, y se quede pequeńo para resultar útil como instrumento de estudio; para terminar la autora Mary Kaldor (2002), [...] la guerra se queda así en un término involucrando la dimensión política y militar para aproximarse a los enfrentamientos armados atendiendo a la pluralidad de planos en que viene a dirimirse el choque de poder. (Aznar, 2014, pp. 3-19) 
De este modo, como en muchos de los conflictos y en la cooperación entre los Estados, es importante tener en cuenta la interacción de otros actores internacionales. En la actualidad los conflictos son de origen multicausal, es decir, se presentan por causas de origen religioso, étnicas o tribales y, por lo general, no se limitan solamente al ámbito militar. Además, otro cambio en la modalidad de conflictos consiste en el crecimiento de los grupos armados que obtienen armamento por medio del tráfico ilícito de armas. Sin embargo, históricamente, la guerra expresó una de las formas de encuentro entre los Estados hasta el final de la Primera Guerra Mundial y la constitución de la Sociedad de las Naciones, aunque posiblemente se debería extender este periodo hasta el final de la Segunda Guerra Mundial y la creación de la Organización de las Naciones Unidas.

$\mathrm{Al}$ respecto, cabe señalar que para Bouthoul (1946) las normas humanitarias formaban parte de un "ilusionismo jurídico", pues no habían servido para regular los usos ni las costumbres de la guerra, como tampoco para evitar nuevas contiendas. Aparentemente, esas primeras aproximaciones del autor francés sobre la importancia jurídica de limitar la tragedia de la guerra estarían parcialmente superadas en un mundo globalizado, en el cual la comunidad internacional persigue actualmente los más graves crímenes cometidos en la guerra (Centro de Estudios de Política y Relaciones Internacionales, 2017).

Por su parte, la perspectiva liberal plantea que un Estado puede estar en paz con otro aunque sus relaciones estén lo suficientemente deterioradas como para entrar en guerra, sin que por ello existan otras formas de relación específicas. En este sentido, la paz es, sin embargo, el elemento habilitante para que se produzca la segunda forma de encuentro entre Estados. Así, los conflictos armados se entienden como un fenómeno histórico que existe desde el comienzo de la historia y que se puede presentar entre distintos pueblos o Estados (Mejía, 2006) o entre el mismo pueblo.

Esta clasificación de los conflictos permite vincular en este estudio la polemología con el DIH, pues este último hace una distinción entre dos tipos de conflictos armados: conflictos armados internacionales (CAI), en los cuales se enfrentan dos o más Estados, y conflictos armados no internacionales (CANI), en los que se enfrentan fuerzas gubernamentales y grupos armados no gubernamentales, $o$ únicamente esos grupos.

Por su parte, los Convenios de Ginebra y el Comité Internacional de la Cruz Roja (CICR) también formulan esta clasificación, pero especifican que el enfrentamiento armado debe alcanzar un nivel mínimo de intensidad y las partes que participan en el conflicto deben poseer una organización mínima para que se considere 
como conflicto armado (CICR, 2001). De hecho, el concepto de conflictos armados hace referencia a todos aquellos enfrentamientos en los que están involucrados las armas y su uso, así como los daños causados a la población en general.

En conclusión, la exposición de este apartado permite afirmar que el conflicto armado colombiano se puede entender y dirimir usando el desarrollo conceptual de la polemología, es decir, es posible entender sus causas desde la visión que ofrece esta ciencia.

\section{Aporte de autores representativos a la comprensión de la polemología en este trabajo}

A continuación se presenta un análisis detallado de la literatura especializada. Específicamente, se consultó la obra de catorce autores relevantes sobre el concepto de polemología, quienes abordan su aplicación desde el conflicto, la metodología y las relaciones con el tema de investigación (tabla 2).

Tabla 2. Aproximaciones de varios autores a la polemología

\begin{tabular}{|c|c|c|}
\hline Título del documento & $\begin{array}{c}\text { Aplicación desde el conflicto. } \\
\text { Metodología }\end{array}$ & $\begin{array}{l}\text { Relaciones con el tema } \\
\text { de investigación }\end{array}$ \\
\hline $\begin{array}{l}\text { Conflicto, política y } \\
\text { polemología en el pensa- } \\
\text { miento de Julien Freund }\end{array}$ & $\begin{array}{l}\text { La polemología, que involucra a un } \\
\text { crítico de la cultura, se centra en la } \\
\text { función social de la guerra, conocida } \\
\text { como la institución más impor- } \\
\text { tante de la destrucción. Comprende } \\
\text { pensamientos, métodos cuantita- } \\
\text { tivos y científicos que interpretan } \\
\text { el neologismo polemología y dan su } \\
\text { razón a una sociología especial, es } \\
\text { decir, la sociología de un conflicto } \\
\text { (Molina, 2000). }\end{array}$ & $\begin{array}{l}\text { El artículo sirve como referente } \\
\text { esencial para comprender de mejor } \\
\text { manera la importancia de los } \\
\text { conflictos internacionales, en espe- } \\
\text { cial en el desarrollo de las guerras } \\
\text { y cómo esto afecta la irenología } \\
\text { (Molina, 2000). }\end{array}$ \\
\hline $\begin{array}{l}\text { La polemología: la } \\
\text { historia militar como } \\
\text { género histórico }\end{array}$ & $\begin{array}{l}\text { Es un género poco cultivado por los } \\
\text { historiadores académicos, especial- } \\
\text { mente por los espańoles, que la han } \\
\text { relegado por atribuirle unas conno- } \\
\text { taciones políticas concretas. Con } \\
\text { entidad propia, no es solo una parte } \\
\text { de la Historia narrativa, y supera la } \\
\text { Historia de las batallas, muy pres- } \\
\text { tigiada en el ámbito anglosajón } \\
\text { y centroeuropeo y polemológico } \\
\text { (Martínez, 2003). }\end{array}$ & $\begin{array}{l}\text { El artículo sirve como referente } \\
\text { esencial sobre la historia de España } \\
\text { y la historia universal contempo- } \\
\text { ránea. Permite comprender de } \\
\text { mejor manera la importancia de los } \\
\text { conflictos internacionales, en espe- } \\
\text { cial en el desarrollo de las guerras, } \\
\text { desde la polemología (Martínez, } \\
\text { 2003). }\end{array}$ \\
\hline
\end{tabular}




\section{$\begin{array}{ccc}\text { Título del documento } & \begin{array}{c}\text { Aplicación desde el conflicto. } \\ \text { Metodología }\end{array} & \begin{array}{c}\text { Relaciones con el tema } \\ \text { de investigación }\end{array}\end{array}$}

Capítulo "La guerra

como función social"

\section{El desarrollo de los últimos conflictos,} con sus enormes secuelas de destrucción y sufrimiento, ha propiciado un aumento de las aspiraciones de paz en todos los estamentos de la sociedad. No obstante esas aspiraciones de paz, el pacifismo tradicional representa un importante obstáculo a la polemología. Sucede que frente a esa corriente social que considera el problema resuelto, Gaston Bouthoul enfrenta la necesidad de elaborar y aplicar métodos científicos al estudio de las guerras. De nada sirve la política de algunos de esos movimientos pacifistas que intentan, mediante la maldición de la guerra y la proposición de buenos sentimientos, detener o impedir unos conflictos bélicos que no entienden ni de razones, ni de benévolas proposiciones. En este sentido, para Gaston Bouthoul, la formulación de las principales doctrinas sobre la paz y la guerra resulta sencillamente decepcionante, con independencia del interés que puedan despertar muchos de los juicios que en ellas se enuncian. Sucede que después de tratar de analizar el fenómeno de la guerra, solo se consigue de los diferentes pensadores opiniones que conducen a maldecirlas o alabarlas. La necesidad de realizar un trabajo mucho más paciente y analítico, sobre los distintos aspectos y mecanismos del fenómeno bélico, debería conducir al entendimiento de las distintas funciones de la guerra y, como consecuencia de ello, a la posibilidad de controlarla y remediarla (Franco, 2000).
El artículo sirve como referente esencial para comprender el pensamiento del autor, quien considera que tradicionalmente ha habido resistencia hacia el estudio de las causas que provocan la guerra (Franco, 2000). 


\begin{tabular}{|c|c|}
\hline Título del documento & $\begin{array}{c}\text { Aplicación desde el conflicto. } \\
\text { Metodología }\end{array}$ \\
\hline $\begin{array}{l}\text { Es posible una polemo- } \\
\text { logía científica }\end{array}$ & $\begin{array}{l}\text { Para el autor Christian Schmidt, la } \\
\text { palabra polemología ha sido intro- } \\
\text { ducida en el vocabulario cientí- } \\
\text { fico inmediatamente después de } \\
\text { la Segunda Guerra Mundial por el } \\
\text { francés Gaston Bouthoul, fundador } \\
\text { del instituto francés del mismo } \\
\text { nombre. Aproximadamente, en la } \\
\text { misma época, el norteamericano } \\
\text { Quincy Wright colocaba las premisas } \\
\text { de una ciencia de la guerra. Desde } \\
\text { este periodo heroico, se han desa- } \\
\text { rrollado programas de investiga- } \\
\text { ciones relativas al estudio científico } \\
\text { de la guerra o de la definición de } \\
\text { las condiciones objetivas de la paz } \\
\text { (Schmidt, 1981). }\end{array}$ \\
\hline
\end{tabular}

Direcciones futuras en conflictos y estudios de paz

Teoría de conflictos de Johan Galtung hacerlo lo más barato y productivo posible (Kenneth, 1978).

El trabajo está organizado en tres capítulos, lo cual obedece a una

\section{Relaciones con el tema de investigación}

El escrito identifica tres formas sucintas de ver el fenómeno de la guerra, la cual puede constituir un objeto científico y que actualmente es una controversia sobre el fenómeno de la guerra según métodos científicos (Schmidt, 1981).

La gran relación del escrito sobre las direcciones futuras en conflictos y estudios de paz es la necesidad de una paz estable. La guerra es el resultado de decisiones humanas hechas en un marco de instituciones humanas y las decisiones son el resultado de las imágenes del mundo y los valores por los cuales estas imágenes son juzgadas por parte del tomador de decisiones (Kenneth, 1978). exigencia expositiva y analítica que facilita al mismo tiempo la presentación y la comprensión de los contenidos. La parte principal del trabajo, el segundo capítulo, referido a la teoría de conflictos de Galtung, ocupa un lugar central en la presentación. Está ubicado entre el primer capítulo, referido a los estudios para la paz, que le da el marco introductorio, así como el escenario histórico teórico, y el tercer capítulo, referido
Este trabajo permite comprender la teoría de los conflictos del sociólogo y matemático noruego Johan Galtung. Muchos teóricos afirman que la obra de Galtung representa estudios para la paz. Asimismo, sus importantes aportes para una epistemología de la paz lo colocan como el punto de referencia más importante en este nuevo campo del conocimiento (Calderón, 2009). 


\begin{tabular}{ccc}
\hline Título del documento & $\begin{array}{c}\text { Aplicación desde el conflicto. } \\
\text { Metodología }\end{array}$ & $\begin{array}{c}\text { Relaciones con el tema } \\
\text { de investigación }\end{array}$ \\
\hline
\end{tabular}

a la transformación de conflictos (método Transcend), que subraya el aspecto aplicativo y metodológico de las tesis expuestas en el capítulo central (Calderón, 2009).

Polemología del Oriente Medio

Polemología y derecho humano al desarrollo: Clausewitz y la cooperación internacional
El documento se divide en dos ítems importantes sobre la polemología de Oriente Medio. Se conoce actualmente como Oriente Medio para diferenciarlo del que hasta principios de siglo — con límites más restringidos a los países ribereños del Mediterráneo Oriental- se conocía como Oriente Próximo. En conjunto, la obra presenta factores permanentes de conflictividad que podrían explicar históricamente los críticos acaecimientos que actualmente tienen lugar en esa región del mundo. Asimismo, respecto a la previsión y prospectiva en la decisión militar, trata de la posible trascendencia y efectividad de los medios convencionales, para lo cual tiene en cuenta la realidad de la innovación que las nuevas tecnologías pueden aportar en el futuro (Cuartero, 2004).

El artículo analiza las posibilidades que el estudio de los desarrollos referentes a la guerra puede brindar al campo de la Corte Interamericana de Derechos Humanos frente a la renovación del paradigma de desarrollo (ahora entendido definitivamente como sostenible) y a la reconfiguración de la relación entre Derechos Humanos, cooperación y desarrollo sostenible. En relación con lo anterior es importante dar una aproximación para hallar nuevas comprensiones y herramientas para avanzar en la concreción del derecho humano al desarrollo sostenible a partir de una relectura de Clausewitz (Surasky, 2017).
El panorama de Oriente Medio que hace este trabajo permite afirmar que, a lo largo de la historia y a partir de recuerdos milenarios, el autor argumenta que entre los pueblos que lo han habitado siempre han existido crisis o enfrentamientos. Esta situación se atestigua en los pasajes bíblicos, que después continuaron entre árabes, bizantinos o persas, que con diversos protagonistas persistieron a través de los siglos hasta finalizar en el actual enfrentamiento árabe-israelí (Cuartero, 2004).

El escrito hace aportes a la práctica de la política internacional, a la cual aborda desde diferentes marcos. Entre ellos se incluyen las Operaciones de Paz de la ONU, específicamente el informe que presentó en 2000 el Grupo sobre las Operaciones de Paz de las Naciones Unidas (documento número $S / 2000 / 809$ ) al Consejo de Seguridad de la Organización. Asimismo, el texto contribuye a comprender la naturaleza y alcance de los Derechos Humanos y la construcción de un desarrollo sostenible. Desde una perspectiva diferente, también se refiere a los vínculos estrechos que existen entre guerra y polemología (Surasky, 2017). 


\begin{tabular}{|c|c|}
\hline Título del documento & $\begin{array}{c}\text { Aplicación desde el conflicto. } \\
\text { Metodología }\end{array}$ \\
\hline Polemología geopolítica & $\begin{array}{l}\text { El artículo tiene una metodología y } \\
\text { un aspecto geopolítico, con su rama } \\
\text { geoeconómica cada vez más acusada. } \\
\text { En definitiva, el análisis detallado de } \\
\text { todo aquello que puede provocar un } \\
\text { conflicto, e incluso degenerar en una } \\
\text { guerra, en las relaciones entre grupos } \\
\text { humanos organizados, no exclu- } \\
\text { sivamente Estados, aunque sigan } \\
\text { teniendo una importancia capital en } \\
\text { el actual mundo globalizado e inter- } \\
\text { dependiente (Bajo, 2020). }\end{array}$ \\
\hline $\begin{array}{l}\text { Gaston Bouthoul, la } \\
\text { guerra como función } \\
\text { social }\end{array}$ & $\begin{array}{l}\text { El artículo tiene una metodología } \\
\text { y un concepto de polemología de la } \\
\text { guerra de todos contra todos. Esta } \\
\text { formulación debe ser aclaradas ya } \\
\text { que el término guerra ha sufrido } \\
\text { una transformación de significado. } \\
\text { El significado más obvio de guerra } \\
\text { se refiere al conflicto entre Estados, } \\
\text { entre ejércitos regulares y ejércitos } \\
\text { irregulares o definidos como guerra } \\
\text { civil entre conflictos dentro del } \\
\text { mismo Estado (Franco, 2000). }\end{array}$ \\
\hline
\end{tabular}

Gaston Bouthoul, la guerra como función social

Protección jurídica internacional de los Derechos Humanos durante los conflictos armados

Como metodología, el artículo hace una investigación analítica que ofrece una orientación y un análisis jurídico exhaustivo a las autoridades

\section{Relaciones con el tema de investigación}

Este análisis señala que no se deban ignorar las visiones clásicas que interpretaban y justificaban los acontecimientos políticos por su vinculación a posiciones geográficas y a antecedentes históricos. En este sentido, define la geopolítica actual como el ejercicio de la actividad encaminada a influir en el plano internacional (Bajo, 2020).

La relación del escrito con el Ser y guerra. Polemología diaria no solo está determinada por un hecho biológico que tiene su origen en la lucha entre genes, ni tampoco por criterios irracionales. Está determinada por la lógica del cálculo sobre la base de una racionalidad que puede imponer momentos de paz en beneficio de las personas vulnerables. Esta protección del más débil contradice el principio del factor biológico en el que el más fuerte se impone y cancela al más débil (Franco, 2000). estatales, a los actores humanitarios y de Derechos Humanos y a otros agentes en relación con la aplicación del DIDH y el DIH para la protección de las personas en situaciones de conflicto armado. Examina, en particular, la aplicación complementaria de estos dos corpus normativos. Su objetivo no es tratar todos los aspectos pertinentes, sino, más bien, proporcionar una visión general de su aplicación concurrente.
Cuando las investigaciones revelan la violación de ciertos derechos reconocidos en el Pacto, los Estados parte deben asegurarse de que los culpables comparezcan ante la justicia. Como sucede cuando no se abre una investigación, el hecho de que no se haga comparecer ante la justicia a los autores de violaciones puede ser de por sí una vulneración del Pacto (ONU, 2011). 


\begin{tabular}{ccc}
\hline Título del documento & $\begin{array}{c}\text { Aplicación desde el conflicto. } \\
\text { Metodología }\end{array}$ & $\begin{array}{c}\text { Relaciones con el tema } \\
\text { de investigación }\end{array}$ \\
\hline
\end{tabular}

Proporciona los necesarios ante-
cedentes y análisis jurídicos de las
nociones pertinentes, a fin de que
el lector pueda comprender mejor
la relación entre ambos conjuntos
normativos, así como las implica-
ciones de su aplicación comple-
mentaria en situaciones de conflicto
armado (ONU, 2011).

Manual de paz y conflictos

Filosofía de la guerra
La paz imperfecta propone y contribuye a la realización de un giro epistemológico en nuestra forma de observar y pensar la realidad, reivindicando la necesidad de reequilibrar una mirada sesgada hacia la violencia. Un desequilibrio que nos hace menospreciar las realidades de la paz y sobredimensionar la violencia en sus múltiples variantes: guerras, armamentismo, pobreza, marginación, etc., mientras que la paz ha sido reducida a un hecho residual y anecdótico, ligada a la ética, pero no a la práctica. De esta manera, se llega a la propia idea de progreso que aparece ligada casi inexorablemente a la capacidad de acción y gestión de la violencia. Finalmente, es posible contemplar la realidad con mayor riqueza y complejidad y puede que sea necesario una reconciliación con nuestra propia historia, una relectura que visibilice las diferentes realidades prácticas, teóricas, epistemológicas (organización de los conocimientos) y características de los seres de la paz (Muñoz, 2004).

La polemología se presenta como una ciencia social de naturaleza interdisciplinar, con todos los rigores asociados a la palabra ciencia y con todos los complejos del apellido
La relación de este trabajo con la presente investigación convive e interactúa en todos los ámbitos. La mayor parte de las prácticas diarias sociales, culturales y políticas son de tipo pacífico, están interrelacionadas, de tal manera que la solidaridad y la cooperación están continuamente presentes, como lo demuestran los índices de bienestar que presenta nuestra realidad social. La paz imperfecta es, ante todo, una herramienta intelectual para conocer, reconocer y potenciar la paz (Muñoz, 2004).

El texto plantea que la guerra es una actividad que escapa al plano militar por donde normalmente es vehiculada. También relata y comprende una actividad inherentemente polí- 


\begin{tabular}{|c|c|c|}
\hline Título del documento & $\begin{array}{c}\text { Aplicación desde el conflicto. } \\
\text { Metodología }\end{array}$ & $\begin{array}{l}\text { Relaciones con el tema } \\
\text { de investigación }\end{array}$ \\
\hline Filosofía de la guerra & $\begin{array}{l}\text { social. De la guerra se ocupará la } \\
\text { polemología, término acuñado en } \\
\text { una fecha tan tardía como } 1945 \\
\text { por un pacifista, el sociólogo francés } \\
\text { Gaston Bouthoul; su cometido } \\
\text { consistiría, según sus palabras, en } \\
\text { "el estudio objetivo y científico de } \\
\text { las guerras como fenómeno social } \\
\text { susceptible de observación". Frente } \\
\text { a ella se encuentra la irenología, } \\
\text { que etimológicamente significa 'el } \\
\text { estudio de la paz' y se ocupa del otro } \\
\text { lado (Aznar, 2014). }\end{array}$ & $\begin{array}{l}\text { tica y dotada de una lógica propia, } \\
\text { es decir, una lógica de transforma- } \\
\text { ción bien distinta de la aproxima- } \\
\text { ción lineal con la que se manejan los } \\
\text { asuntos cotidianos. En este sentido, } \\
\text { la guerra es una realidad social que } \\
\text { precisa ser estudiada científicamente } \\
\text { desde un punto de vista de la igno- } \\
\text { rancia (Aznar, 2014). }\end{array}$ \\
\hline
\end{tabular}

Fuente: Elaborado por el autor.

\section{Relación de las guerrillas comunistas con el conflicto armado colombiano después de 1950}

El conflicto colombiano se formalizó en los años sesenta, pero su génesis y los embriones de las tensiones se encuentran en la década de 1950, cuando se presentaron grandes acontecimientos que sirvieron de plataforma y base, como el periodo de La Violencia, que proyecta el futuro conflictivo más inmediato al concatenar los escenarios de la tenencia de la tierra con el olvido estatal (Conflicto, 2017). Este proceso desencadenó la aparición de las dos guerrillas más representativas: las Fuerzas Armadas Revolucionarias de Colombia (FARC) y el Ejército de Liberación Nacional (ELN).

El conflicto armado colombiano ha sido violento y extenso, pero, ante todo, político, y ha tenido como factor principal la disputa por el territorio. Precisamente, para Duncan (2015), en este conflicto ha sido importante gobernar comunidades periféricas durante tiempo indefinido, sin importar cuánto dure, para extraer toda una serie de recursos, desde económicos hasta políticos. De este modo, actores ilícitos podían disponer de santuarios de impunidad desde donde acumular riqueza. Además, la naturaleza del conflicto es compleja, pues se configuraron grupos de guerrilla independientes en la década de los sesentas, como las FARC, el Movimiento 19 de Abril (M19), el Ejército Popular de Liberación (EPL) y el ELN, además de grupos de autodefensa conocidos como grupos paramilitares y bandas criminales, que pertenecieron a los carteles del narcotráfico en la década de 1980 (Restrepo \& Aponte, 2009). 
Igualmente, la tortura, los tratos crueles, inhumanos o degradantes han sido una constante contra los actores del conflicto, ya sean combatientes o población civil, durante todos los años de violencia que ha vivido Colombia. Muestra de ello son las cifras que ha recopilado la Coalición Colombiana contra la Tortura entre 2001 y 2009, en la cual se evidencia que por lo menos 1.834 personas fueron víctimas de tortura, de las cuales 422 quedaron con vida, 1.148 fueron asesinadas y 264 fueron víctimas de tortura psicológica. Esta entidad también reporta que por cada 100 hombres víctimas de tortura, se presentan 15 casos contra mujeres, y que en el 90,59\% de los casos está comprometida la responsabilidad del Estado por perpetración directa, omisión o aquiescencia al accionar de los grupos paramilitares, mientras que el 9,41\% se atribuye a grupos al margen de la ley (Restrepo, 2014).

El conflicto colombiano ha mantenido una continua vulneración respecto a las personas indefensas desde La Violencia (1946-1957). Esta situación se agravó aún más cuando aumentaron los contingentes de hombres armados y la confrontación bélica se intensificó entre finales del siglo XX y principios del XXI. Aunque pudo haber dado la impresión de que el conflicto se degradó, en realidad presentó un aumento exponencial en la magnitud de las acciones armadas, que generaron sentimientos de dolor a la sociedad (Granada, Restrepo \& Sánchez, 2009).

Para la antropóloga y politóloga Gloria Naranjo (2001), la sociedad colombiana vivió a su vez una aguda fragmentación social derivada del desplazamiento interno forzado, que ha involucrado diversas víctimas que no pertenecen a una etnia, a una religión, a una clase o a un grupo social específico. Esto trajo consigo no solamente cambios y reestructuraciones en las culturas locales y nacionales, sino también en las normas tradicionales de convivencia. Como consecuencia, en Colombia se acumularon entre 1993 y 1998 diferentes tipos de violencias, como las que menciona Galtung (2016, pp. 147-168):

a. La violencia cultural se define como un aspecto de una cultura que puede ser utilizada para legitimar la violencia en su forma directa o estructural.

b. La violencia estructural son situaciones en las que se produce un daño en la satisfacción de las necesidades humanas básicas (supervivencia, bienestar, identidad o libertad).

c. La violencia simbólica introducida, como la violencia directa o utilizada en la explotación o como la violencia incorporada en una estructura. Sin embargo, se utiliza para legitimar ambas o una de ellas, como por ejemplo en el concepto de raza superior. 
En 1958, los colombianos votaron por sus representantes en elecciones libres y competidas entre los partidos, cosa que no hacían desde hacía once años. Las mujeres eligieron presidente por primera vez en la historia. Teniendo en cuenta estos antecedentes, se puede afirmar que el Frente Nacional ${ }^{10}$ se instituyó como una doble transición: de la guerra a la paz y de la dictadura a la democracia, con logros que han sido objeto de una intensa discusión académica y política (Giraldo, 2015).

También se debe mencionar que en Colombia ha sido determinante la producción de cultivos ilícitos como factor de afianzamiento del conflicto armado interno, pues desde el punto de vista geográfico es un lugar privilegiado para el cultivo de la amapola debido a que tiene una de las zonas de páramo tropical más grandes del mundo, que van de los 1.800 a los 3.200 metros sobre el nivel del mar (Ramírez, 1993). De hecho, se calcula que en estas zonas se produce el $80 \%$ del total de la producción de coca en el mundo, de manera que los grupos armados ilegales han encontrado en esta planta su principal fuente de financiamiento para la guerra (Díaz \& Sánchez, 2004).

\section{Relación del DIH y la polemología como fundamento normativo para analizar el ataque de grupos ilegales contra la población civil de Bojayá (Chocó)}

A través de la historia, el DIH ha tenido como propósito limitar los métodos y acciones en el desarrollo de la guerra para evitar el sufrimiento humano en tiempos de conflicto armado. Con este propósito se han adoptado distintos tratados, que son normas universales que restringen los impactos del conflicto armado con el objetivo de proteger la vida e integridad de las personas civiles (Organización de Estados Americanos [OEA], 2014).

El DIH contemporáneo tiene sus orígenes en dos fuentes principales: (1) el Derecho de Ginebra, una normativa destinada a proteger las víctimas de la guerra, y (2) el Derecho de La Haya, un conjunto de disposiciones que regulan la conducción de las hostilidades. Bugnion (2001) analiza los diferentes principios en que se basan esas dos ramas del DIH y expone su desarrollo histórico hasta la Conferencia Diplomática de 1974-1977, en la cual se aprobó el Protocolo Adicional I e hizo converger las dos ramas jurídicas.

10 El Frente Nacional se refiere a un acuerdo político entre liberales y conservadores para terminar con el partido presidencial del general Rojas Pinilla. Dentro de sus características se encontraba la alternancia de la presidencia, la distribución de los ministerios, entre otras (Silva, 1989). 
Mientras que el CICR ha sido indudablemente el principal promotor del Derecho de Ginebra, su contribución al desarrollo y a la aplicación del Derecho de La Haya ha sido menos explícita. En la actualidad, todo acercamiento al derecho humanitario implica una preocupación por ambas corrientes del derecho, ya que constituyen partes inseparables del DIH moderno (Bugnion, 2001).

En el caso de América Latina, el objetivo fundamental del DIH, al decir de la Corte IDH, es "restringir la contienda armada para disminuir los efectos de las hostilidades" (Corte IDH, caso "La Tablada" Avella vs. Argentina, 1997).

Además, los diferentes tratados que constituyen lo que se denomina el Derecho de Ginebra tienen por objeto la suerte que corren las personas que han dejado de combatir o que han caído en poder de la parte oponente. Los Estados codificaron, paralelamente y en varias etapas, las normas internacionales que habrían de imponer límites a la conducción de las operaciones militares: el llamado Derecho de La Haya — cuyos principales exponentes son los distintos Convenios de La Haya de 1907_, que tiene la finalidad primordial de restringir la guerra a ataques contra objetivos necesarios para el resultado de las operaciones militares. La población civil, por consiguiente, ha de ser protegida contra los ataques militares (Gasser, 1998). De acuerdo con el CICR, es importante tener en cuenta los tratados proferidos recientemente, los cuales se exponen en la tabla 3.

Tabla 3. Tratados que forman parte del DIH

Ańo Tratados que forman parte del DIH

1864 Convenio de Ginebra para el mejoramiento de la suerte que corren los militares heridos en los ejércitos en campaña.

1868 Declaración de San Petersburgo (prohibición del uso de determinados proyectiles en tiempo de guerra).

1899 Convenios de La Haya sobre las leyes y costumbres de la guerra terrestre y sobre la adaptación a la guerra marítima de los principios del Convenio de Ginebra de 1864.

1906 Revisión y desarrollo del Convenio de Ginebra de 1864.

1907 Revisión de los Convenios de La Haya de 1899 y aprobación de nuevos Convenios.

1925 Protocolo de Ginebra sobre la prohibición del empleo, en la guerra, de gases asfixiantes, tóxicos o similares y de medios bacteriológicos.

1929 Dos Convenios de Ginebra:

1) Revisión y desarrollo del Convenio de Ginebra de 1906.

2) Convenio de Ginebra relativo al trato de los prisioneros de guerra (nuevo). 
1949 Cuatro Convenios de Ginebra:

1) Para aliviar la suerte que corren los heridos y los enfermos en las fuerzas armadas en campaña.

2) Para aliviar la suerte que corren los heridos, los enfermos y los náufragos de las fuerzas armadas en el mar.

3) Relativo al trato debido a los prisioneros de guerra.

4) Relativo a la protección debida a las personas civiles en tiempo de guerra.

1954 Convención de La Haya para la protección de los bienes culturales en caso de conflicto armado.

1972 Convención sobre la prohibición del desarrollo, la producción y el almacenamiento de armas bacteriológicas (biológicas) y tóxicas y sobre su destrucción.

1977 Tres Protocolos Adicionales a los Convenios de Ginebra de 1949 que mejoran la protección de las víctimas de los conflictos armados internacionales (Protocolo I) y no internacionales (Protocolo II) y prohibiciones o restricciones (Protocolo III). Convención sobre prohibiciones o restricciones del empleo de ciertas armas convencionales que puedan considerarse excesivamente nocivas o de efectos indiscriminados. A ella se añaden:

El Protocolo I sobre fragmentos no localizables.

El Protocolo II sobre prohibiciones o restricciones del empleo de minas, armas trampa y otros.

El Protocolo III sobre prohibiciones o restricciones del empleo de armas incendiarias.

1993 Convención sobre la prohibición del desarrollo, la producción, el almacenamiento y el empleo de armas químicas y sobre su destrucción.

1995 Protocolo sobre armas láser cegadoras (Protocolo IV [nuevo] de la Convención de 1980).

1996 Protocolo enmendado sobre prohibiciones o restricciones del empleo de minas, armas trampa y otros artefactos (Protocolo II [enmendado] de la Convención de 1980).

1997 Convención sobre la prohibición del empleo, almacenamiento, producción y transferencia de minas antipersonal y sobre su destrucción.

1998 Estatuto de Roma de la Corte Penal Internacional.

1999 Protocolo a la Convención de 1954 para la protección de los bienes culturales.

2000 Protocolo facultativo de la Convención sobre los Derechos del Niño relativo a la participación de niños en los conflictos armados.

2001 Enmienda al artículo 1. ${ }^{\circ}$ de la Convención sobre ciertas armas convencionales. 


\begin{tabular}{cc}
\hline Año & \multicolumn{1}{c}{ Tratados que forman parte del DIH } \\
\hline 2005 & $\begin{array}{l}\text { Protocolo Adicional a los Convenios de Ginebra del 12 de agosto de 1949 rela- } \\
\text { tivo a la aprobación de un signo distintivo adicional (Protocolo III) (Comité } \\
\text { Internacional de la Cruz Roja, 2004). }\end{array}$ \\
\hline
\end{tabular}

Fuente: Elaborado por el autor con datos del Comité Internacional de la Cruz Roja (2004).

Así como es importante precisar y entender los tratados que forman parte del DIH, la polemología también busca analizar y entender los diferentes factores que pueden originar las guerras o los conflictos armados, de manera que analiza qué y quiénes son los que están protegidos en dichas normativas. Si bien se reconoce que puede haber un derecho a la guerra, también debe ser de pleno conocimiento quiénes son los que participan en ellas y qué lugares y bienes se involucran. En el caso de Colombia, las partes involucradas en el conflicto no han cumplido este principio, pues los ataques por parte de los grupos al margen de la ley han sido indiscriminados y contra bienes que estarían protegidos por el DIH.

Específicamente, los hechos de violencia que tuvieron lugar el 2 de mayo de 2002 en las zonas urbanas de Bellavista y Vigía del Fuerte (Cabecera municipal de Bojayá, Departamento del Chocó) fueron ocasionados por la disputa entre integrantes de las Autodefensas Unidas de Colombia (AUC) y los guerrilleros de las Fuerzas Armadas Revolucionarias de Colombia (FARC) por el control geográfico de las rutas de acceso al río Atrato, corredor apetecido para transportar drogas e ingresar armas y dinero a Centroamérica.

La confrontación entre estos grupos ilegales cobró la vida de aproximadamente trescientas personas inocentes que se refugiaron de los enfrentamientos en la iglesia y en la casa cural de San Pablo Apóstol. Lamentablemente, en ese lugar estalló un cilindro bomba que el Frente 58 de las FARC lanzó contra los integrantes de las Autodefensas Unidas de Colombia, cuando más de mil guerrilleros se enfrentaron a 250 paramilitares por el control del territorio, entre los municipios de Bellavista y Vigía del Fuerte.

De acuerdo con García (2012), experto en alta gerencia de la defensa nacional, muchas de las víctimas quedaron mutiladas y sus cuerpos esparcidos por todo el lugar, en tanto que los sobrevivientes salieron a buscar refugio en otras partes. Días después, investigadores de la Fiscalía General de la Nación y la Fuerza Pública se hicieron presentes en el lugar de los hechos para hacer el levantamiento de los cadáveres y realizar su respectiva identificación. Sin embargo, muchos de ellos fueron enterrados en fosas comunes porque no fue posible identificarlos. 
En este episodio violento se evidencia la responsabilidad criminal de las FARC, que terminó por quebrantar la legitimidad social y política del país. Además, muestra de manera alarmante el rechazo, el desamparo y la soledad en la que viven el conflicto los pobladores de esta región de Colombia (“Agonía sin fin...", 2014).

En este punto es importante entender la posición geográfica de Bojayá. El municipio se encuentra en el Departamento del Chocó y limita por el norte con la "República de Panamá y el mar Caribe, por el oriente con los departamentos de Antioquia, Risaralda y Valle del Cauca, con el que también limita al sur, y por el occidente con el océano Pacífico" (Sánchez, 2010). Según datos del Departamento Administrativo Nacional de Estadística (DANE), esta región contaba en el 2009 con una población de 471.605 habitantes, de los cuales el $74 \%$ son afrocolombianos y el $11 \%$ corresponde a población indígena. Un poco más de tres quintas partes del territorio del departamento corresponde a la cuenca hidrográfica del río Atrato, que tiene una superficie de $35.000 \mathrm{~km}^{2}$ y un recorrido de $750 \mathrm{~km}$, de los cuales $508 \mathrm{~km}$ son navegables. Este afluente se divide en tres partes: Alto, Bajo y Medio Atrato, donde se sitúa el municipio de Bojayá y es considerado como uno de los lugares del planeta con mayor recurso biogeográfico (Sánchez, 2010).

Por su posición geográfica, Bojayá reúne un atractivo especial para la confrontación armada por el territorio entre varios actores:

- Fuerzas Armadas Revolucionarias de Colombia (FARC).

- Ejército de Liberación Nacional (ELN).

- Ejército Revolucionario Guevarista (ERG).

- Los grupos paramilitares de las AUC.

- Bloques Élmer Cárdenas en el Bajo y Medio Atrato, y Pacífico y Calima en el sur del departamento.

- La Fuerza Pública opera en el Bajo Atrato a través del Batallón Voltígeros de la XVII Brigada del Ejército Nacional.

- Batallón Manosalva de la IV Brigada, que opera en el Medio y Alto Atrato.

- Armada Nacional, con presencia en el Litoral Pacífico.

- Policía Nacional, con los Comandos Departamentales de Policía de Chocó y Urabá (Vicepresidencia de la República, 2007).

En ese orden, se observa que la distribución de los grupos armados en el Departamento del Chocó no es homogénea, pues estos cubrían las diferentes zonas de manera dispar, toda vez que en una sola región podría haber presencia al mismo tiempo de bandas emergentes de AUC, ELN y FARC, quienes luchaban por causas y controles geográficos de este territorio (García, 2012). 
Como se explicó anteriormente, la región del Atrato es una zona geográfica estratégica para que los actores del conflicto armado desarrollen sus actividades económicas ilícitas a través del río Atrato como una vía que permite el acceso al océano Pacífico, lo cual facilita el contrabando de armas y el control de rutas de transporte y exportación de cocaína por la frontera con Panamá. A esto se suma la débil presencia estatal, una ventaja que les ha permitido usar la fuerza sin ninguna restricción para lograr el control sobre este territorio. Con el fin de ejercer su poderío militar, los actores mencionados atacaron el municipio de Bojayá el 2 de mayo de 2002 y sometieron a las comunidades negras e indígenas que habitaban allí a vivir una de las grandes tragedias humanitarias en la historia de Colombia. Entre las consecuencias de índole sociológico que ocasionó la masacre se encuentran:

- Alto número de víctimas mortales de niños, mujeres cabezas de hogar y adultos mayores.

- Los hechos ocurrieron en un lugar simbólico y de carácter sagrado (iglesia).

- Desplazamiento forzado masivo.

- Uso de artefacto explosivo no convencional.

- Daños socioculturales a las poblaciones afro e indígenas de Bojayá.

- Lesión a la identidad cultural (muertes de ancianos portadores de sabiduría).

El sector de la población antes descrito comprende minorías históricamente excluidas y discriminadas, como las comunidades afrodescendientes e indígenas, a quienes se les ha violentado su derecho al territorio por cuanto han sido forzadas a desplazarse, lo cual ocasiona profundos daños morales, culturales y sociológicos. Este hecho, y algunos otros, son prueba de que no todos los actores siguen los parámetros que establece el DIH, situación que puede empeorar y aumentar los factores generadores del conflicto, especialmente el demográfico, ya que por este motivo las ciudades se han sobrepoblado.

Además de las vulneraciones al DIH asociadas a la masacre del 2 de mayo de 2002, también se constata la ausencia estatal, lo cual llevó a las víctimas a interponer masivamente demandas contra el Estado. No obstante, a pesar de haber tenido sentencias a favor, en la práctica no se ha materializado el cumplimiento de dichas providencias, por lo cual se convierte en un acto formal que revictimiza.

Dentro de los fallos se destaca la decisión que el Tribunal Administrativo de Chocó emitió el 28 de mayo del 2015, radicado n. ${ }^{\circ}$ 27001-23-31-000-200400431-02, en la cual se declaró como responsable por los daños antijurídicos a la Nación (Ministerio de Defensa, Armada Nacional, Ejército Nacional, Policía 
Nacional). Asimismo, ordenó el pago de una indemnización económica y una reparación simbólica a las víctimas por violación de los Derechos Humanos y el Derecho Internacional Humanitario, específicamente, violación del derecho a la vida, la integridad personal y las normas de los Convenios de Ginebra, uso de armas no convencionales y todas aquellas que se desprenden de los hechos ocurridos en la masacre de Bojayá.

La decisión judicial evidencia que la justicia colombiana reconoce la responsabilidad del Estado por la ausencia de autoridades militares y policiales, teniendo en cuenta la numerosa presencia de integrantes de las FARC y de las AUC. En tal sentido, ha ordenado que los mandatarios locales, como es el caso del presidente de Colombia, doctor Iván Duque Márquez, deben establecer líneas de política de seguridad nacional que permitan garantizar la vida de la población civil en zonas donde se manifieste presencia y amenazas de Grupos Armados Organizados, como sucede actualmente en esa región del país.

\section{La relación entre actores y acciones violatorias de los Derechos Humanos en el ámbito político y social del conflicto armado en Colombia a partir del ataque de grupos ilegales contra la población civil de Bojayá}

En el conflicto armado colombiano han convergido diferentes fenómenos en ámbitos sociales, económicos, políticos y culturales. Específicamente, este estudio se centra en el aspecto político y social, con el fin de determinar las causas y los efectos de la masacre de Bojayá, en un contexto que presenta diversas amenazas y afectaciones a los Derechos Humanos.

Aunque en el desarrollo del conflicto armado colombiano intervinieron diversos fenómenos, como se mencionó, los de tipo político y social han sido los más determinantes en este proceso. A continuación, se mencionan algunas de las causas más importantes de la violencia en Colombia (Solimano et al., 1999).

Colombia es un país multicultural que congrega diferentes opiniones, creencias, costumbres e ideologías. Esta divergencia se profundiza y transforma en un problema estructural cuando los ciudadanos o los grupos políticos y sociales no tienen igualdad de posibilidades para participar en escenarios de toma de decisión, lo cual produce iniquidades que se convierten en factores generadores de violencia. Además, las instituciones políticas son captadas por entes ilícitos o por individuos 
que operan en función de sus intereses personales y en desmedro de la sociedad en general, de manera que se crea una desconfianza hacia el Estado.

En un breve contexto, se puede decir que la ausencia del Estado en gran parte del territorio nacional ha generado unos "espacios vacíos" que fueron ocupados por grupos al margen de la ley, un fenómeno histórico que Solimano et al. (1999) han denominado "repúblicas independientes" apartadas del Estado. De igual manera, la corrupción, el clientelismo y el manejo de maquinarias políticas para el reparto del poder han sido, entre otros, los factores responsables de que el conflicto se haya profundizado. Cabe agregar que el narcotráfico no solo ha permeado los ámbitos políticos, económicos, sociales e incluso culturales, sino que además se ha consolidado como parte de las economías ilegales que los grupos armados al margen de la ley estructuran para financiarse.

En consecuencia, los altos índices de corrupción, la poca credibilidad de las instituciones estatales y la impunidad en ciertos casos de violencia han provocado que la sociedad recurra a los conflictos para afrontar y resolver estas diferencias. De este modo, las características del conflicto colombiano han sido la magnitud de su extensión, la perdurabilidad y los efectos negativos sobre la población. Al respecto, Trejos (2013) amplía los ámbitos social y político del conflicto colombiano:

- Recurrente persistencia de la violencia con motivaciones políticas por parte de distintos actores políticos y sociales.

- El Estado colombiano históricamente ha mantenido una "presencia" diferenciada en el territorio nacional.

- La descripción del conflicto se encuentra relacionada con la naturaleza de sus actores (Trejos, 2013, pp. 57-58).

En este sentido, se puede afirmar que la violación de los Derechos Humanos en el ámbito político y social del conflicto armado en Colombia tiene diversas causas: políticas, la ausencia del Estado en numerosas regiones del país; económicas, la pobreza y la falta de oportunidades, por ejemplo el empleo digno, y culturales, el aumento del interés sobre el número de hijos y la falta de educación. A continuación, en la tabla 4 se mencionan los principales actores sociales que estuvieron involucrados en el desarrollo de la violencia política en Colombia (Solimano et al., 1999). 
Tabla 4. Principales actores involucrados en la violencia política en Colombia

\begin{tabular}{|c|c|c|}
\hline Generación & Grupo & Sucesos \\
\hline \multirow{2}{*}{$\begin{array}{l}\text { Primera } \\
\text { generación }\end{array}$} & $\begin{array}{l}\text { Grupos políticos } \\
\text { tradicionales: liberales } \\
\text { y conservadores }\end{array}$ & $\begin{array}{l}\text { - Insurrección urbana del Bogotazo, seguida por la violencia, } \\
\text { guerra civil rural entre liberales y conservadores. } \\
\text { - Se establece la paz política cuando los dos partidos princi- } \\
\text { pales comparten el poder en un "Frente" Nacional. } \\
\text { - Amplia percepción de que las elecciones presidenciales de } \\
\text { la década del } 70 \text { fueron fraudulentas, lo cual lleva al surgi- } \\
\text { miento del grupo guerrillero M-19. En este contexto se } \\
\text { decreta el Estatuto de Seguridad Nacional de Turbay. } \\
\text { - El Estado se ve debilitado por las acusaciones de que el } \\
\text { presidente Samper recibió financiamiento electoral de los } \\
\text { carteles de la droga (Solimano et al., 1999, pp. 68-73). }\end{array}$ \\
\hline & $\begin{array}{l}\text { Movimiento } \\
\text { guerrillero }\end{array}$ & $\begin{array}{l}\text { - Grupos comunistas de autodefensa se mantienen activos en } \\
\text { las zonas cafetaleras y las montañas remotas. } \\
\text { - Actividades guerrilleras a nivel nacional: se crean las FARC, } \\
\text { el EPL y el ELN. } \\
\text { - Las FARC se enfrentan en combates con las Fuerzas } \\
\text { Armadas. Protegen a los cocaleros, crean impuestos a los } \\
\text { carteles de la droga, extorsionan y secuestran. } \\
\text { - El colapso de la Guerra Fría incrementa la dependencia } \\
\text { económica de las drogas (FARC) y el petróleo (ELN). } \\
\text { - Conflicto entre las Fuerzas Armadas y la guerrilla } \\
\text { (Solimano et al., 1999, pp. 68-73). }\end{array}$ \\
\hline \multirow{4}{*}{$\begin{array}{l}\text { Segunda } \\
\text { generación }\end{array}$} & $\begin{array}{l}\text { Movimiento } \\
\text { guerrillero }\end{array}$ & $\begin{array}{l}\text { Entre los principales grupos guerrilleros, el M-19 opta por } \\
\text { la lucha armada para conseguir la representación política. } \\
\text { Se firman acuerdos de paz con varios grupos. }\end{array}$ \\
\hline & $\begin{array}{l}\text { Productores de coca } \\
\text { y marihuana }\end{array}$ & $\begin{array}{l}\text { Conflictos asociados con la producción de la coca, los } \\
\text { cuales involucran a las Fuerzas Armadas y a los carteles } \\
\text { protegidos por la guerrilla. } \\
\text { - La guerrilla protege los laboratorios y las operaciones de la } \\
\text { droga. }\end{array}$ \\
\hline & $\begin{array}{l}\text { Carteles e intermedia- } \\
\text { rios de la droga }\end{array}$ & $\begin{array}{l}\text { Conflicto violento relacionado con el control y la organiza- } \\
\text { ción del narcotráfico. } \\
\text { - Penetración violenta de las zonas agrícolas con el propósito } \\
\text { de adquirir tierra para ganadería y la producción comer- } \\
\text { cial de coca. Se presenta la creciente colaboración con los } \\
\text { grupos paramilitares. }\end{array}$ \\
\hline & Fuerzas paramilitares & $\begin{array}{l}\text { - Privatización de las fuerzas de seguridad por medio de la } \\
\text { creación de los "grupos de autodefensa". Ocurren hechos } \\
\text { de terrorismo contra la población en las áreas dominadas } \\
\text { por la guerrilla para controlar rutas comerciales de la coca } \\
\text { que son accesibles a los militares (Solimano et al., 1999, } \\
\text { pp. 68-73). }\end{array}$ \\
\hline
\end{tabular}

Fuente: Elaborado por el autor con base en Solimano et al. (1999). 
Entre todos los hechos violentos que han ocurrido en el marco del conflicto armado en Colombia, no cabe duda de que el ataque a Bojayá es uno de los más emblemáticos en el Departamento del Chocó. Esta flagrante violación de los Derechos Humanos evidencia que los diversos grupos que luchaban por el dominio del control geográfico de la región emplearon el uso planificado y repetido de la masacre como estrategia terrorista, de tendencia exterminadora, premeditada y seviciosa, que deja ver la bajeza en la que se recrudece la guerra. Cabe agregar que los actos de violencia de los grupos al margen de la ley en esta región del Pacífico colombiano incluyen también desplazamientos forzados, homicidios, desaparición forzada, violaciones y múltiples vejámenes contra los Derechos Humanos.

A manera de síntesis, a continuación se presentan los actores que convergen en el desarrollo histórico del conflicto armado colombiano:

1. Al inicio, la violencia por medio de la confrontación armada se limitaba solamente a las guerrillas y las Fuerzas Armadas del Estado. Posteriormente, al conflicto entraron otros actores: los carteles de la droga y los grupos paramilitares.

2. Los actores ilegales se han estabilizado en áreas conocidas como "espacios vacíos", donde el Estado tiene poca presencia institucional. Esto ha provocado que dichos actores se disputen esos territorios y que, por lo tanto, en estas zonas haya altos índices de violencia.

3. Las personas con bajos recursos económicos y que no tienen fácil acceso a la educación constituyen la población que más ha sido afectada durante el desarrollo del conflicto. En ocasiones, debido a la precariedad de su situación, los individuos se vinculan a grupos al margen de la ley como una salida a los problemas que deben afrontar.

4. La mayoría de las víctimas del conflicto armado en Colombia son producto de motivaciones políticas y violación a los Derechos Humanos (Solimano et al., 1999).

Además de los actores ilegales que estuvieron involucrados en el desarrollo de la confrontación en Colombia, se señala que el Estado también ha sido identificado como el principal agente de violencia política. Con el fin de tener una visión más amplia sobre este tema, a continuación se relacionan los actores y las acciones violatorias de los Derechos Humanos en los conflictos armados en el mundo (tabla 5). 
Tabla 5. Actores que participan en los conflictos o guerras que se desarrollan en el campo internacional

\begin{tabular}{|c|c|}
\hline Actores & Acciones \\
\hline $\begin{array}{l}\text { Fuerzas } \\
\text { gubernamentales }\end{array}$ & $\begin{array}{l}\text { - Detenciones o desapariciones arbitrarias. } \\
\text { - La tortura y el maltrato en los centros de detención. } \\
\text { - Violencia sexual. } \\
\text { - Muerte bajo custodia de autoridades. } \\
\text { - Uso de productos químicos tóxicos en un ataque. } \\
\text { - Uso de municiones internacionalmente prohibidas. } \\
\text { - Uso de armas incendiarias. } \\
\text { - Bloqueo a la ayuda humanitaria. }\end{array}$ \\
\hline $\begin{array}{l}\text { Grupos insurgentes } \\
\text { (acciones del orden } \\
\text { nacional } \\
\text { o internacional) }\end{array}$ & $\begin{array}{l}\text { - Ataques con artillería contra civil, secuestros y ejecuciones. } \\
\text { - Uso de armas químicas. } \\
\text { - Bombardeo intencional de objetivos civiles, secuestros, detenciones } \\
\text { arbitrarias, ejecuciones y asedios ilegales. } \\
\text { - Atentados suicidas. } \\
\text { - Atentados con coches bomba. } \\
\text { - Ataque y ejecución de civiles. } \\
\text { - Discriminación y severas restricciones, incluida la libertad de circulación } \\
\text { a mujeres y niñas. } \\
\text { - Tortura, violación, asesinato y esclavización sexual a mujeres y niños. } \\
\text { - Ejecución de hombres acusados de homosexualidad. }\end{array}$ \\
\hline $\begin{array}{l}\text { Los grupos armados } \\
\text { no estatales contrarios } \\
\text { al gobierno }\end{array}$ & $\begin{array}{l}\text { - Ataques indiscriminados contra civiles. } \\
\text { - Uso de niños soldados. } \\
\text { - Secuestros. } \\
\text { - Bloqueo ilegal de la ayuda humanitaria y torturas. }\end{array}$ \\
\hline Ofensivas aéreas & $\begin{array}{l}\text { - Bombardeo indiscriminado contra áreas civiles (escuelas, hospitales, } \\
\text { mercados, hogares). } \\
\text { - Uso de explosivos de gran alcance, bombas de barril, municiones en } \\
\text { racimo y armas incendiarias de materiales inflamables. }\end{array}$ \\
\hline $\begin{array}{l}\text { Refugiados internos } \\
\text { y externos }\end{array}$ & $\begin{array}{l}\text { - Víctimas de incesantes ataques aéreos, los bombardeos, la detención } \\
\text { arbitraria generalizada y sistemática, el maltrato, la tortura y las desapari- } \\
\text { ciones forzadas. } \\
\text { - Limitación por parte de países vecinos con barreras ilegales de tipo } \\
\text { administrativo, jurídico e incluso físico. } \\
\text { - Problemas para consolidar los reasentamientos, disminución de los } \\
\text { recursos de ayuda y restricción de acceso a la tierra. }\end{array}$ \\
\hline Actores internacionales & $\begin{array}{l}\text { - Fracaso en intervención por parte del Consejo de Seguridad de la ONU. } \\
\text { - Violación de tratados internacionales de Derechos Humanos. } \\
\text { - Negativa de países para garantizar el acceso humanitario. } \\
\text { - Restricción para las violaciones de los Derechos Humanos, DIH y DICA } \\
\text { por parte de algunos gobiernos para el uso indiscriminado de arma- } \\
\text { mento dentro del conflicto. }\end{array}$ \\
\hline
\end{tabular}

Fuente: Elaborado por el autor con datos de Giraldo (2008), Merchán (2017) y ONU (2011). 
La información que se presenta en la tabla 5 es importante porque traza las bases y la ruta que ha tenido el conflicto armado en Colombia, de manera que permite establecer cuáles son las razones que mantienen y prolongan este conflicto armado. En la medida en que los gobiernos de turno lo comprendan y logren desarrollar alternativas que mitiguen, reduzcan y cambien estas bases, se podrá disminuir $y$ atenuar la violencia del conflicto armado. De igual forma, es importante enfatizar que para superar estas falencias es necesario que haya más presencia institucional, no necesariamente mayor número de militares, sino otras figuras administrativas, con buenas políticas públicas que permitan reemplazar las actividades que puedan fomentar el accionar de los grupos armados al margen de la ley. Sin embargo, valga aclarar, la presencia militar es necesaria, pues los actores que promueven el conflicto han consolidado estructuras "militarizadas" que deben ser combatidas por las Fuerzas Armadas con acciones que respeten los Derechos Humanos y el DIH. En este sentido, se entiende que en el ataque de Bojayá se cometieron actos bélicos o violaciones a tratados internacionales, como:

- Delitos de lesa humanidad contemplados en el Protocolo II Adicional a los Convenios de Ginebra.

- El empleo de armas no convencionales.

- Tratos crueles e inhumanos a la población civil (torturas, genocidio).

- Artículo 3. ${ }^{\circ}$ común a los cuatro convenios de Ginebra de 1949.

- Artículo 13. ${ }^{\circ}$ del Protocolo II Adicional (distinción).

Estas graves violaciones a los Derechos Humanos protegidos por la normativa internacional demuestran que los hechos que tuvieron lugar el 2 de mayo del 2002 en Bojayá (Chocó) revisten especial gravedad en el marco del conflicto armado colombiano.

Para concluir este trabajo, a continuación se abordan los principales aspectos de la regulación internacional que protegen los Derechos Humanos en contextos bélicos. Como se mencionó, el DICA es la parte del derecho internacional público (DIP) que establece las normas de comportamiento que deben seguir las partes de un conflicto armado internacional. Tiene como propósito limitar el conflicto a las fuerzas adversarias y minimizar la posibilidad de que las personas que no participan del conflicto se conviertan en víctimas. Asimismo, se señala que existen innumerables métodos pacíficos para regular los conflictos, normalmente referidos a la negociación, la mediación o la reconciliación, cada uno de los cuales dispone de técnicas para trabajar con los conflictos y, más importante aún, dilucidan el propósito de limitar el conflicto de las fuerzas adversarias (Muñoz, 2004). 
Con el fin de proteger la población civil y los bienes civiles, el DICA determina que las partes en conflicto deben aplicar el principio de distinción, es decir, deben distinguir a la población civil de los combatientes y diferenciar entre bienes civiles y objetivos militares, de tal manera que solo podrán dirigir sus operaciones a los objetivos militares (CICR, 2002). Al respecto, el profesor Hernández (2000) considera que se debe mantener la definición consagrada por el DIH y que las normas en conjunto protegen a los no combatientes.

Como resulta evidente en este punto, en la masacre de Bojayá no hubo aplicación del principio de distinción, pues la población civil estaba refugiada en un sitio simbólico y sagrado, lo cual constituye una infracción del DICA.

En consecuencia, es necesario entablar escenarios de protección de los Derechos Humanos para todos y cada uno de los individuos que sufren las consecuencias de la confrontación bélica. Por este motivo, es de vital importancia incluir el DICA como herramienta para enfrentar las acciones de las fuerzas no gubernamentales tanto internas como extranjeras.

\section{Conclusiones}

El municipio de Bojayá es apetecido por diferentes actores armados debido a que se encuentra en una zona geográfica estratégica que permite el acceso a las fronteras para el comercio ilegal de armas y cocaína. Precisamente, con el fin de lograr el control de esta zona, el 2 de mayo del 2002 los grupos armados sometieron a la población bojayaseña a una de las más grandes tragedias humanitarias en la historia de Colombia por las consecuencias de índole sociológico que se derivaron: alto número de víctimas mortales de niños, mujeres cabeza de hogar y adultos mayores; los hechos ocurrieron en un lugar simbólico y de carácter sagrado (iglesia); provocó desplazamiento forzado masivo; se usó un artefacto explosivo no convencional; se produjeron daños socioculturales a las poblaciones afro e indígenas de Bojayá, y se lesionó la identidad cultural (muertes de ancianos portadores de sabiduría). Este ataque plantea una reflexión desde la polemología, definida como "el estudio objetivo y científico de las guerras, como fenómeno social susceptible de observación" (Bouthoul, 1946), pues este hecho violento es una manifestación desbordada del conflicto interno que trasladó sus efectos a la parte más vulnerable de la sociedad.

En este escenario, se debe enfatizar que no obstante el Estado colombiano tiene el deber de proteger a todos los miembros de la sociedad, presenta carencias en el ejercicio de dicho deber que desembocan en vejámenes contra la población civil más vulnerable. Este es el caso de las víctimas de la masacre de Bojayá, quienes 
sufrieron el abandono estatal: ausencia de la Fuerza Pública, falta de normatividad en materia de protección de los Derechos Humanos y, posteriormente, en justicia restaurativa de sus derechos.

Este análisis contextualiza el conflicto armado colombiano en el Departamento del Chocó — con especial énfasis en el municipio de Bojayá - siguiendo los postulados de la polemología, desde la cual se han presentado varias interpretaciones acerca del desarrollo de la violencia en Colombia que convergen en los ámbitos sociales, económicos, políticos y culturales. Uno de los factores que se mencionaron consiste en que actores políticos actúan conforme a sus intereses personales en menoscabo del bien común, lo cual deriva en situaciones de corrupción, clientelismo, entre otros delitos.

Asimismo, a lo largo de esta investigación se evidenció que los conflictos o guerras se deben a diversos factores generadores, cuyo reconocimiento y comprensión resultan de gran importancia no solo para resolver las problemáticas que aquejan a la sociedad luego de los hechos violentos que la afectan, sino además para reparar y mejorar a largo plazo el bienestar de las personas y promover una calidad de vida digna, en la cual los seres humanos gestionen los conflictos pacíficamente y satisfagan al máximo sus necesidades.

El análisis crítico que se realizó sobre la influencia del DICA en relación con la polemología y su aproximación al conflicto armado colombiano en el municipio de Bojayá, departamento del Chocó, permitió observar las trasformaciones propias de los Estados y del sistema internacional. En efecto, el concepto de guerra ha quedado limitado, ya que no cubre todas las causas ni las consecuencias de los fenómenos de violencia que se desarrollan, y no alcanza a definir la naturaleza de los orígenes de los conflictos. Por lo tanto, se puede afirmar que dicho término debe ser ampliado para incluir el tratamiento de amenazas emergentes que determinan las nuevas guerras en el siglo XXI.

Respecto a la relación entre la polemología y el DICA, como fundamento normativo, se puede concluir que, en la actualidad, la polemología tiene un papel muy importante en la comprensión y resolución de los conflictos armados, ya que busca hacer efectivas las garantías de no repetición, considerada una de las formas de reparación a las víctimas y uno de los principios generales de responsabilidad internacional de los Estados. Las garantías de no repetición comprenden dos dimensiones: una preventiva y otra reparadora, con el fin de evitar la revictimización de la población vulnerable. Por lo tanto, se considera importante estudiar en profundidad la polemología en el marco del DICA debido a su particularidad científica, por cuanto investiga las causas profundas y determinantes que provocan las guerras para evitarlas en el futuro. 
Si bien han existido distintos autores, como Julien Freund, que hablan sobre la polemología, es Bouthoul quien se enfoca en los estudios sociológicos y científicos, sus causas y fenómenos, con el objetivo de observar los detalles y diversos aspectos de los conflictos. En este sentido, aplicando la teoría bouthouleana para el caso colombiano, el Estado debería diseñar una política pública de control criminal sobre las regiones apartadas del país, para evitar confrontaciones sorpresivas sobre la población civil que se encuentra indefensa en estas zonas.

Desde de la óptica de los autores analizados, se concluye que la polemología es una disciplina que se interesa por el estudio de la guerra aplicado a la paz. No obstante, se debe tener en cuenta que hay tres cosas que la polemología no puede hacer: suprimir las guerras, resolver los conflictos ni aportar previsiones coyunturales a corto plazo. Solamente puede establecer la génesis de los conflictos para prevenirlos a largo plazo investigando científicamente a fondo los acontecimientos, las coyunturas, las tendencias y las estructuras involucradas en los conflictos para proponer alternativas políticas y sociales en busca de la paz.

Asimismo, a partir de los autores militares Carl von Clausewitz y Antoine Henri Jomini, surge la necesidad de estudiar el concepto de guerra y los conflictos armados desde la perspectiva sociológica, de manera que se pueda entender el origen de la confrontación armada que implican el uso de la fuerza, las acciones, los actores y las circunstancias que eventualmente amenacen con infringir el DIH.

Por su parte, la teoría de los conflictos del matemático y sociólogo noruego Johan Galtung constata que los conflictos son una constante en la historia de la humanidad. Son, como afirma este autor, inherentes a todos los sistemas vivos en cuantos portadores de objetivos. De acuerdo con Galtung, en algunas etapas de la historia fueron como la force motrice que contribuyeron a generar verdaderos cambios en provecho del hombre, pero en otras, trascendiéndose a sí mismos y convirtiéndose en violencia, los conflictos condujeron hacia la deshumanización absoluta; de ahí su importancia y sentido para la vida y el destino de las personas. En este sentido, la irenología aporta ideas, medios y acciones para que, siempre que surja un conflicto, se pueda canalizar hacia una solución que no origine violencia, y eso solo es posible empleando medios pacíficos. Por lo anterior, por ejemplo, el único fin de la mediación es concebir el fenómeno de la paz para buscar soluciones pacíficas a los conflictos.

La guerra y las políticas en cualquier parte del mundo han generado un costo muy alto, que se constata en el impacto que han tenido en el desarrollo evolutivo del hombre y en el colapso de la paz negativa. Por esta razón, sería pertinente tener en cuenta el trabajo de Kenneth E. Boulding, quien plantea que es necesario hacer 
un registro de la investigación sobre la paz para evitar una amenaza a la supervivencia de la raza humana mucho mayor que la pobreza y la injusticia.

En conclusión, los conflictos armados alrededor del mundo han servido para que los pueblos tomen medidas y construyan conciencia acerca del impacto social de los costos económicos y sociales que generan las situaciones de conflicto. Por esta razón es importante investigarlos — teniendo en cuenta a las víctimas directas y a la población en general_- pues están relacionados con la política y el desarrollo económico del país, y, de manera especial, con los Derechos Humanos y la importancia de la vida, la integridad y la libertad de las personas.

\section{Conflicto de intereses}

El autor declara que no existe ningún potencial conflicto de interés relacionado con este capítulo.

\section{Financiación}

El autor no declara fuente de financiamiento para la realización de este capítulo.

\section{Referencias}

Agonía sin fin: 12 años de la masacre de Bojayá. (2014, febrero 5). Semana. https://www.semana.com/ nacion/articulo/masacre-de-bojaya-12-anos-despues/385639-3

Aznar Fernández, F. (2014). Filosofía de la guerra. http://arbor.revistas.csic.es/index.php/arbor/article/ view/1898/2108

Aznar Fernández, F., \& Montesinos, F. (2011). Entender la guerra en el siglo XXI. Universidad Complutense de Madrid.

Bajo, P. (2020). Polemología geopolítica. Ejército de Tierra, 8(37), 16-19. https://dialnet.unirioja.es/ servlet/articulo? codigo $=3400628$

Borda, S. (2007). La internacionalización del conflicto armado después del 11 de septiembre Colombia Internacional, 65, 66-89. https://revistas.uniandes.edu.co/doi/pdf/10.7440/colombiaint65.2007.03

Bouthoul, G. (1946). Polemología o guerra. https://dialnet.unirioja.es/descarga/articulo/1957182.pdf Bugnion, F. (2001, diciembre 31). El Derecho de Ginebra y el Derecho de La Haya. https://www.icrc. $\mathrm{org} / \mathrm{spa} /$ resources/documents/misc/5tdqeh.htm

Calderón Concha, P. (2009). Teoría de conflictos de Johan Galtung. Revista Paz y Conflictos, 2, 60-81. https://www.ugr.es/ - revpaz/tesinas/rpc_n2_2009_dea3.pdf

Centro de Educación e Investigación [CINEP] (s. f.). [Página institucional]. https://www.cinep.org.co/ Home2/institucion/nosotros.html. 
Centro de Estudios de Política y Relaciones Internacionales. (2017, mayo 2). Significado polemológico de la victimización de miembros de la Policía Nacional. https://cepri.upb.edu.co/index. $\mathrm{php/transicion-militar-y-policial-en-colombia/significado-polemologico-de-la-victimiza-}$ cion-de-miembros-de-la-policia-nacional

Clausewitz, K. V. (2002). De la guerra. http://lahaine.org/amauta/b2-img/Clausewitz\%20Karl\%20 von\%20-\%20De\%20la\%20guerra.pdf

Comité Internacional de la Cruz Roja [CICR]. (2004, enero 1). ¿Qué tratados forman parte del Derecho Internacional Humanitario? https://www.icrc.org/spa/resources/documents/misc/5tdlja.htm

Conflicto, R. d. (2017). Breve historia del conflicto armado en Colombia. Revista de Paz y Conflictos, 10(1), 327-330. https:/www.redalyc.org/pdf/2050/205052042015.pdf

Cruz Roja. (2002). El Derecho de los Conflictos Armados. Conocimientos básicos y reglas de comportamiento. Cruz Roja de España.

Cuartero, M. (2004). Polemología del Oriente Medio. En El cambio climático y su repercusión en la defensa (pp. 191-195). Instituto Español de Estudios Estratégicos.

Díaz, A. M., \& Sánchez, F. (2004). Geografía de los cultivos ilícitos y conflicto armado en Colombia [Documento Cede 2004-18]. https://core.ac.uk/download/pdf/6517082.pdf

Duncan, G. (2015, febrero 1). Contribución al entendimiento del conflicto armado en Colombia. http://www.humanas.unal.edu.co/observapazyconflicto/files/5714/6911/9376/Version_final_ informes_CHCV.pdf

Ecola de Cultura de Pau [ECP]. (2017). Escola de Cultura de Pau. https://escolapau.uab.cat/diplomatura/presentacion-2/

Fisas, V., \& Mayor Zaragoza, F. (2006, marzo 1). Cultura de paz y Gestión de conflictos. UnesCo.

Franco, F. J. (2000). Gaston Bouthoul: la guerra como función social. Ministerio de Defensa de Espańa. https://dialnet.unirioja.es/servlet/articulo?codigo=595156

Galtung, J. (2004). Violencia, guerra y su impacto. http://red.pucp.edu.pe/ridei/wp-content/uploads/ biblioteca/081020.pdf

Galtung, J. (2016). La violencia cultural, estructural y directa. Cuadernos de Estrategia, 183, 147-168. https://dialnet.unirioja.es/servlet/articulo? codigo $=5832797$

Gasser, H. (1998, noviembre 1). El Derecho Internacional Humanitario y la protección de las víctimas de la guerra. https://www.icrc.org/spa/resources/documents/misc/5tdle2.htm

Garay, C., \& Ramírez, E. (2017). Los factores estratégicos de Colombia en seguridad y su influencia en el posicionamiento regional en el posconflicto. https://esdeguelibros.edu.co/index.php/ editorial/catalog/view/19/16/102-1

García, M., (2012). Breve análisis de la masacre de Bojayá, Departamento del Chocó en mayo de 2002 bajo la perspectiva de los Derechos Humanos y el Derecho Internacional Humanitario [Ensayo de especialización, Universidad Militar Nueva Granada]. Repositorio Unimilitar. https://repository.unimilitar.edu.co/bitstream/handle/10654/7550/GarciaEstupinanMiguelAngel2012. pdf? sequence $=2$ \&isAllowed $=y$

Giraldo Ramírez, J. (2015). Comisión histórica del conflicto y sus víctimas. http://www.centrodememoriahistorica.gov.co/descargas/comisionPaz2015/GiraldoJorge.pdf

Giraldo, Y. (2008). Violación del Derecho Internacional Humanitario por parte del Estado colombiano. Anu. Mex.Der. Inter, 8, 223-253. http://www.scielo.org.mx/scielo.php?script=sci_arttext\&pid=S1870-46542008000100006 
Granada, S., Restrepo, J. A., \& Sánchez Meertens, C. (2009, julio 6). Guerra y violencias en Colombia: herramientas e interpretaciones. En Jorge A. Restrepo, \& David Aponte (Eds.), Controlando la medición: alcances y limitaciones de la información en conflictos armados (pp. 203-231). Pontificia Universidad Javeriana.

Guadarrama, P. (2016). Dirección y asesoría de la investigación cientifica. Magisterio.

Harvard Kennedy School. (2019). Belfer Center for Science and International Affairs. https://www. belfercenter.org/research

Hernández, A. (2000). El derecho de los conflictos armados no internacionales. https://dialnet.unirioja. es/descarga/articulo/6302351.pdf

Hernández Sampieri, R., Fernández Collado, C., Baptista Lucio, P., Méndez Valencia, S., \& Mendoza Torres, C. (2014). Metodología de la investigación. McGraw-Hill Educación.

Kenneth E., B. (1978). Direcciones futuras en conflictos y estudios de paz. El diario de resolución de conflictos. Revista de Economía Crítica, 8(1), 342-354. http://www.ugr.es/ revpaz/numeros/ revpaz_8_1_completo.pdf

Martínez, J. L. (2003). La polemología: "la historia militar" como género histórico. Cuadernos de Historia Contemporánea, [número extraordinario], 37-47. https://revistas.ucm.es/index.php/ $\mathrm{CHCO/article/view/CHCO0303220037A/6872}$

Mejía Azuero, J. C. (2006). La Corte Penal Internacional y las Fuerzas Armadas de Colombia: Una mirada desde las trincheras. Biblioteca Jurídica Dike.

Merchán, A. (2017). Conflicto armado y violación de Derechos Humanos en el Departamento de Arauca [Trabajo de especialización, Universidad Militar Nueva Granada]. Repositorio Unimilitar. https:// repository.unimilitar.edu.co/bitstream/handle/10654/15958/MerchanTorresAdrianaMarcela2017. pdf;jsessionid=FF84420F22D85A3735344A93797C396B?sequence $=1$

Ministerio de Defensa Nacional. (2016). Directiva Ministerial N.º 15 del 2016.

Molina, J. (2000). Conflicto, política y polemología en el pensamiento de Julien Freund. Barataria Revista Castellano-Manchega de Ciencias Sociales, 2-3, 203. https:/dialnet.unirioja.es/servlet/ articulo? codigo $=2154252$

Muñoz, F. (2004). Regulación y prevención de conflictos. En Francisco Muñoz (Coord.), Manual de paz y conflictos (pp. 173-200). Universidad de Granada. https://www.fondodeculturaeconomica.com/PDF/Caja\%20de\%20herramientas/Regulacion_y_Prevencion_de_Conflictos.pdf

Naranjo, G. (2001). El desplazamiento forzado en Colombia. Reinvención de la identidad e implicaciones en las culturas locales y nacional. Scripta Nova Revista Electrónica de Geografía y Ciencias Sociales, 94(1), s. p. http://iep.udea.edu.co:8180/bibliotecaiep/bitstream/recursos/200/1/GNaranjo5.pdf

Organización de Estados Americanos [OEA]. (2014, enero 31). Derecho Internacional Humanitario. http://www.oas.org/es/sla/ddi/derecho_internacional_humanitario.asp

Organización de las Naciones Unidas [onu]. (2011). Protección jurídica internacional de los Derechos Humanos durante los conflictos armados. ONU.

Queirel, R. (2018). La polemología ¿̇iencia o ficción? Visión Conjunta, 10(18), 30-35. http://www. cefadigital.edu.ar/bitstream/1847939/1067/1/VC\%2018-2018\%20QUEIREL.pdf

Ramírez, M. C. (1993). El cultivo de amapola en Colombia. En Consulta técnica internacional sobre el cultivo ilícito de amapola en Latinoamérica. Ministerio de Justicia; Oficina de las Naciones Unidas contra la Droga y el Delito. 
República de Colombia. (2007, abril 4). Sentencia-C291/07. Persona protegida por el Derecho Internacional Humanitario. https://www.corteconstitucional.gov.co/relatoria/2007/C-291-07.htm

Restrepo, J. (2014). Situación de tortura en Colombia. https://relapt.usta.edu.co/images/CoalicionColombiana-contra-la-Tortura-Situacion-de-Tortura-2014.pdf

Restrepo, J., \& Aponte, D. (2009). Guerra y violencia en Colombia: Herramientas e interpretaciones. Pontificia Universidad Javeriana.

Rivera, V. A. (2007, diciembre 7). La tenencia de la tierra: un problema en Colombia. https://prensarural.org/spip/spip.php?article1288

Ruiz, N. (2011). El desplazamiento forzado en Colombia: una revisión histórica y demográfica. Estudios Demográficos y Urbanos, 26(1), 141-177. https://www.redalyc.org/pdf/312/31224198005.pdf

Sánchez G., G. (Coord.). (2010). Bojayá. La guerra sin límites. Taurus. http://www.centrodememoriahistorica.gov.co/descargas/informes2010/informe_bojaya.pdf

Schmidt, C. (1981, octubre). Es posible una polemología científica [Boletín de información 148 del Ministerio de Defensa, Centro Superior de Estudios de la Defensa de España]. https://dialnet. unirioja.es/descarga/libro/413843.pdf

Silva Luján, G. (1989). Carlos Lleras y Misael Pastrana: reforma del Estado y crisis del Frente Nacional. En Nueva Historia de Colombia: Historia politica 1946-1986 (vol. II, pp. 237-262). Editorial Planeta.

Solimano, A., Saez, F., Moser, C., \& López, C. (1999). Ensayos sobre paz y desarrollo. El caso de Colombia y la experiencia internacional. Tercer Mundo. http://documents.worldbank.org/ curated/en/248251468746671754/pdf/2159410paper.pdf\#page $=24$

Surasky, J. (2017). Polemología y derecho humano al desarrollo: Clausewitz y la cooperación internacional. Rev. IUS, 11(40), 7-27. http://www.scielo.org.mx/pdf/rius/v11n40/1870-2147rius-11-40-00007.pdf

Swirnarski, C. (1990). Direito Internacional Humanitàrio. Revista Dos Tribunais.

Tenencia de la tierra, raíz del conflicto en Colombia, llave de la paz. (2019, diciembre 12). Agronoticias: Actualidad Agropecuaria de América Latina y el Caribe. http://www.fao.org/in-action/agronoticias/detail/es/c/510891/.

Trejos, L. (2013). Colombia: una revisión teórica de su conflicto armado. Revista Enfoques, 11(18), 55-75.

Tribunal Administrativo de Chocó. (2015, mayo 28). Sentencia N.o 27001-23-31-000-2004-0043102. Magistrado ponente: José Rojas.

Valencia Villa, A. (1989). Derecho Internacional y conflicto interno. Colombia y el Derecho de los Conflictos Armados. CINEP.

Verri, P., Duque Ortiz, M., \& Cabrera, R. (2008). Diccionario de Derecho Internacional de los Conflictos Armados. Comité Internacional de la Cruz Roja.

Vicepresidencia de la República. (2007). Diagnósticos departamentales: Chocó, Risaralda, Valle del Cauca, Occidente Antioqueño, Córdoba, Antioquia. Observatorio del Programa Presidencial de Derechos Humanos y Derecho Internacional Humanitario; Vicepresidencia de la República.

Villafañe, E. (1971). Polemología o guerra. Revista de Estudios Políticos, 176-177, 147-161. 